\author{
PROPAGANDA TEORISI \\ ve \\ PROPAGANDANIN GELISSIMI (*)
}

\author{
Dr. Terence H. QUALTER \\ Waterloo Universitesi \\ IÇev. Ünsal OSKAY]
}

\title{
Bölüm I :
}

\section{PROPAGANDA TEORISI}

1622 yilının Haziran ayında Papa XV. Gregory, zamanin Avrupa'sında, Kilise kurumunun durumunu yeniden düzenlemek zorunda kalmıştır. Ogünlerde Bohemya, Alsas ve Palatinate'da din savaşları yeniden başlamıştı. Ama papa biliyordu ki bunlar silâh zoruyla yeniden dinde birlik kurmaya yetmeyecekti. Zaman böyle bir iş için artık çok geç olmuştu. Protestan Reform Hareketinin etkilerine karşı mücadele edebilmek için, yeni koşullar nedeniyle, yeni önlemler almak gerekiyordu. İşte bütün bu düşüncelerledir ki Para Gregory Katolik Kilisesinin imân ve inancını barış̧ı yollardan yaymak için yeni, örgütlü ve sürekli bir kuruluşun oluşturulmasını düşündüğünü bildirdi. Bunun ardından, 22 Haziran'da, Sacra Congregatio Christiano Nomini Propaganda; ya da bugün daha çok hatırlanan adıyla, Sacra Congregatio de Propaganda Fide kuruldu. Bu kurulus Roma Katolik Kilisesinin resmi bir organı oldu ve Katolik Kilisesinin inanç ve imânını yeni dünyaya yaymak, aynı zamanda eski dünyada da Roma Kilisesinin din anlayışını pekiştirmek ve yeniden güçlendirmekle görevlendirildi. Sacra Congregatio, propaganda görevlerini yüklenmek için kurulan ilk organ değildi. Bu işi yapan ve özel olarak da böyle bir isimle adlandırılan ilk kuruluş oluyordu.

Papalığa bağh bu resmi Propaganda kurumu kurulduktan sonra kilise görevlilerinin bireysel anlayıştaki çalışmaları sona ermiş; onun

(*) "Propaganda Teorisi" ve "Propagandanın Gelişimi" başlıklannı taşıyan bu çeviriler, Kanada'daki Waterloo Universitesi profesörlerinden Dr. Terence Qualter'in Propaganda and Psychological Worfare (Propaganda ve Psikolojik Savaş) kitabının birinci ve ikinci bölümleridir. 
yerine, merkezì otoritenin kontrol ve yönetiminde tek bir hareket tarzı izlenmeye başlanmış; Katolik-olmayan ülkelerde âyin dualarında kullanılan kitaplar ile piskoposlann ve diğer kilise görevlilerinin misyonerler için hazırladıkları eserlerin biçim ve işlemleri üzerinde merkezî bir denetime gidilmiştir. Birkaç yıllık bir dönem içinde, 1627'de Papa VIII. Urban, misyonerler için merkezde bir okul açmak amaciyla, Collegium Urbanum'u kurmuştur.

Propaganda Kurumunun çalışmaları geniş çapta ve "topluluk bilincine" seslenecek nitelikteydi; yani, bireylere değil, "Amerikalar'daki puta tapanlar" ile "Avrupa'daki protestan halklara" seslenilmekteydi.

Propagarda kuruluşunun denetiminde ve genel bir çerçeve içinde hazırlanan bu materyallerin erişilmek istenen kitlelere sunulmasında izlenecek yöntemlerin ve diğer sunum ayrntılannın saptanması ise, içinde çalışılacak ülkelerin ogünkü koşullarnna göre yerel Kilise görevlilerine terk edilmiş bulunmaktaydı. Bu propaganda çalışmasında merkezin tesbit ettiği genel çalışma ilkesi ise, insanlara Roma Kilisesinin doktrinini gönüllü olarak benimsetmekti. ${ }^{1}$

Katolikliği sistemli bir şekilde yaymak için geliştirilen Gregory'nin bu plânının, kurucusunun düşündüklerini aşan, iki sonucu daha oldu : birincisi, daha sonralar kamu oyunu kontrol etmek, böylece kitlelerin eylemlerini güdümlemek isteyen başka propagandacılara bir örnek oluşu; ikincisi, kamu oyunun günümüzdeki biçimiyle kontrol edilmesiyle sonuçlanan uygulamaları kolaylaştırmış oluşu. Başlangiçta kelime olarak ilk anlamiyla ve herhangi bir doktrini yaymak için kurulan örgütleri ifade etmek amaciyla kullanılan propaganda terimi, zamanla, doktrinin kendisini ifade etmek için kullanılmış; sonraları ise, doktrini yaymak için yararlanılan teknikleri ifade etmekte de kullanılmaya başlamıştır. Önlerinde papalık tarafınsan geliştirilen örneğe bakan kuzeyli Protestan ülkeler propaganda terimine güneydeki Katolik ülkelerindekinden çok farklı, sakıncalı ve bozguncu, bir anlam vermişlerdir. Ondokuzuncu yüzyılda yaşayan bir İngiliz yazarı için Roma Katolik Kilisesinin inancını yaymak amacıyla kurulan bir örgütü kötü ve yıkıcı bir örgüt olarak kabul etmek; bu ikisini es anlamlandırmak olağandi. Nitekim 1840'larn önde gelen ansiklopedistlerinden W.T. Brande, Papa Gregory'nin bu kuruluşunun tarihçesini özetledikten sonra terime ilişkin olarak şu yorumu yapiyordu :

I Papalığın Propaganda çalışmalarının tarihçesi ve tanıtimı için, Bk: U. Benigni",

"Propaganda," Catholic Encyclopaedia, Yll (1911), ss. 456-461. 
Köken olarak bu eski kuruluştan adını alan propaganda çağdaş siyaset dilinde, çoğu yönetimlerin dehşet ve nefretle karşıladı̣klar ilke ve düşünceleri yaymak için kuurlmuş gizli örgütleri ifade etmekte kullanlmaktadir. ${ }^{2}$

Yukardaki alıntıdaki şekli dışında, onyedinci ve onsekizinci yüzyll boyunca İngilizcede "propaganda" hakkında hemen hemen hiçbirşey şey yazılmamıştır. Fakat bu dönemden hemen sonra, "propaganda" bütün dünyada siyasal bilimcilerin en çok kullandıkları kavramlardan biri olmuştur.

Doğaldır ki, propaganda faaliyetleri ve ikna teknikleri toplumlarla yaşıt olduğu için, hiç de yeni şeyler değildir. İnsanın örgütlü topluluklarda yaşamaya başlamasıyla birlikte liderler ve liderliğe özenenler kendilerine destek bulmak için propaganda yöntemlerini kullanmıslardır. Mısır'daki piramitler, Romanın lejyonlarındaki düzen ve gösterişlilik, Kuzey Amerika'daki kabilelerin totemlerle süslü ağaçtan sütunları bu topluluklardaki liderliklerin mistik görünümlerini pekiştirmek, topluluk üyelerindeki topluluğun üyesi olma duygusunu güçlendirmek, toplulukların birlik ve yaşayış biçimini sağlamlaştırmak için kullanılmış propaganda düzenekleriydi. Düşmanın kendine olan güven ve cesaretini kırmak veya düşmana karşı nefret duyguları yaratmak için imâl edilen zulüm ve gaddarlı "masalları" en azından savaşlar kadar tarihi eski tekniklerdir. Her savaşın ardından, heriki tarafın da zulmünü ve kötülüklerini işleyen böylesi hikâyeler yaygınlaşmıştır, tarih boyunca.

Bununla beraber, propagandanun siyasal hayatın içinde devamIl ve temel önemde bir görünüm kazanması ve geniş kapsamlı, örgütlü bir propagandanın oluşması için gerekli koşullar ancak ondokuzuncu yüzyıldaki ulus devletleriyle birlikte ortaya çıkabildiği için, esas itibarıyla propaganda çağdaş sayılabilecek bir olgudur. Bu koşullar; yani, kitlesel propaganda için gerekli ön-koşullar gelecek bölümde ayrintılariyla incelenecektir.

Burada, şimdilik, propagandanın rekläm tekniklerinin siyasete uygulanmasıyla oluşmaya başlayıp, daha sonra, başlı başına ayrı bir uzmanlık türü gerektiren bir sanat hâlini aldığını belirtmekle yetinelim. Oondokuzuncu yüzyl sonlarında çok az sayıdaki ileri görüşlü bazı siyasal bilimciler propagandanın demokrasi için potansiyel bir tehdit niteliği taşıdığını işaret etmişlerdir. Fakat 1914 yılın-

2 W. T. Branda, "Propaganda," Dictionary of Science, Literature and Art (London. 1842), 
da demokrasi için tehdit teşkil edeceği ileri sürülen propagandanin yerini, siyastç̧ilerin yaptıkları mücadelede kitlelerden destek sağlamak için kullandıklan rüşvet, yolsuzluk ve şiddet kullanımınin aldığı görüldü. Gene de, o dönemde bile, bazı siyasal bilimcilerce çağdaş siyasetin en önemli öğelerinden biri olduğu ileri sürülen propaganda birçoklar için henüz hiç duymadıkları bir kavram olmaktà devam ediyordu. Wallas'ın, Sorel'in, Lippmann'in kitaplam küçük bir aydınlar azınlığından başkasına ulaşamıyor; geniş kitleler, çoğunlukla, propaganda sorunundan habersiz bulunuyorlardı.

1914-1918 Savaşı ise propaganda pratikleri alanında denemeler yapmak için çok geniş olanaklar hazırlamıştır. Savaşın sonunda pekçok insan modern propaganda teknikleri konusunda birinci elden deneyim sahibi olmus bulunuyordu. 1920'lerin ortasinda, modern propaganda konusunda yaşamlanyla deneyim sahibi olan kimseler kendi anılarını yayınlamaya başlamış; propaganda kelimesi artık çoğunluğun bildiği bir kelime olmus ve günlük siyaset sözlügümüzde yer almıştır.

Birinci Dünya Savaşındaki propaganda, özellikle Müttefiklerin uyguladiğı propaganda ilerde oldukça ayrintılı olarak incelenecektir. Bunun nedeni, Birinci Dünya Savaşındaki propagandanın ulusal çerçevede olduğu kadar, uluslararası boyutları içinde de oldukça uzun bir zaman kamu oyunun kontrol altına almması için girişilmiş ilk sistemli çaba oluşudur. Bu bakımdan, I. Dünya Savaşı döneminin propaganda çalışmalarının incelenmesi propagandanın doğasının (mahiyetinin) anlaşılması için de yararlı olacaktır. 1930'larda ileri sürülen propaganda tanımlarından çoğu bu eserde pek ciddiye alınmamıştır. Bunun nedeni, bu tür tanımların kendilerini propagandacı olarak ilân eden kimselerin faaliyetlerini açıklamaktan uzak oluşudur. Bu eserde, propaganda konusunda geliştirilecek bir teorinin, herşeyden önce, propagandacının yaptıklamnı açıklığa kavuşturması gerektiği inancı ile hareket edilmiştir.

\section{ANLAMLARIN YOLAÇTIĞI KARIŞIKLIK}

1919 yılında, büyük devletlerin herbiri öylesine karmaşlk örgütler kurmuş, propaganda "güç mücadelesinde" öylesine önemli bir silâh hảline gelmiştir ki, siyasal bilimciler için, yapılacak herhangi bir siyaset süreci incelemesinde propagandanın konu dışı bırakulması olanaksızlaşmıştır. Fakat aynı siyasal bilimciler ilk olarak "propaganda" diye neleri incelemek zorunda olduklarını saptamak gereğini 
duymuşlardır. Bunun nedeni ise, o dönemde propagandanın doğası konusunda tam bir karışıklığın hüküm sürmesi olmuştur. 1914-1918 Savaşının kapsadığı dönemde propaganda terimininin günlük yaşanṭ̣daki kullanımı kelimenin alışılmış anlamının sınırlarını aşmıs; fakat terime, üzerinde görüş birliğine varılmış bir anlam sınırlanımı getirememişti. Bu dönemde "propaganda" terimi hem isim, hem de sufat olarak kullanılıyor; hem aldatmaca, hem karşllıkı tarafların herikisince de söylenen "yalanlar" yerine geçiyor; hem bir eylem biçimini, hem de bu eylem biçiminde kullanlan materyalleri ifade ediyor; ayrica, bugün psikolojik savaş dediğimiz sürecin çeşitli görünümlerini kapsamı içinde bulunduruyordu. Siyasal bilimciler propaganda konusundaki incelemelerini sistemleştirmek için, herşeyden önce, bu terimi yeniden tanımlamak zorunda kalmışlardı. Fakat ne yazık ki, siyasal bilimcilerin o dönemde yaptıkları yeniden-tanımlamalar crtadaki güçlüğü daha da arttırmış; bu çabalar başarısızlıkla sonuçlanmıştır. Bu bölümün amaçlarından biri de propaganda kavramını tanımlamak için girişilen sözkonusu çabalan ve bu konudaki çeşitli yaklaşımları özetle gözden geçirmektir.

Bu konuda, 1923 yllında R.J.R.G. Wreford tarafindan sunulan bir tezdeki tanımlama yerinde bir başlangıç olabilir. Yazar propaganda kelimesinin "çirkin" bir kelime olduğunu ileri sürdükten sonra, propaganda'nın "ilgi çekici enformasyon ve kanaat yayma işlemi" olduğunu söylemiştir. Yazara göre, propagandanin bundan fazla ya da eksik bir yanı bulunmamaktadır. Yaylmak istenen materyalin gerçek ya da yalan, olgusal ya da kanaat niteliğinde olması; veya iyilik için ya da kötülük için yayılmak istenmiş olması bir fark yaratmamaktadır. Ayrıca, propagandanın büyük ölçüde hissiyata hitap eden bir işlem omlasına ya da yayım yöntemlerinin de diğer alanlardakilerden farklı ve özel yöntemler olması gerektiğine dikkat edilmediği anlaşlmaktadır. Wreford'un tanımında, sadece, propagandanın "ilgi çekici" olması; yani, belirli bir fikrin veya kanaatın "satışından" bir takım kazançların elde edileceği umudunu uyandırması özelliği üzerinde durulmuştur. ${ }^{3}$

Fakat Wreford sıradan propagandadan ayrı olarak, "kötü niyetli propagandayı da" belirtmiştir. Bu, ilgi çekici görünen, ama aslında ilgi çekici [yarar sağlayıcı] olmayan; bu özelliğini saklı tutan propagandadır. Kötü niyetli propaganda sadece enformasyon verme amacını taşıyormuş gibi görünerek propagandacının kitlenin kanaatları.

3 R.J.R.G. Wreford, "Propaganda, Evil and Good," The Nineteenth Century and After, XCIII (1923), ss. 514-24. 
nı etkileme arzusunu ashında sinsice gözlerden uzak tutar. Daha sonraki bazı yazarlar propagandanın anlamını ikna edici tarafin amacının gizli tutulduğu ikna biçimleriyle sinırlı tutmak istemişlerse de, Wreford'un ileri sürdüğg̈ gerek açık gerekse saklı iknanın propaganda sayrlabileceği görüşü bizçe çok daha akla yakı̣ ve yeterli görünmektedir.

Wreford'un tanımındaki kısalık ve sadelik bir üstünlük niteliği taşıyorsa da, söylenmesi gereken pekçok şeyi ifáde edemeyen bir tanum tam olmayacağı açıktır. Propaganda elbette ki ilgi çekici fikir ve kanaatların yaygınlaştırılmasıdır. Ama, aynı zamanda, bundan fazla birşeydir. Böyle bir tanıma bakarak, bu tanımı yapan yazarın bir üniforma giymek, bir bayrak asmak, bir borazan çalmak gibi şeyleri de propaganda eyleminin kapsamı içinde sayıp saymadığını anlamak olanaksızdır. Yüzeyden bakılırsa, Wreford'un propagandadan anladığı sözlü ya da yazılı dil aracılığ̀l ile fikir ve görüşlerin yaygınlaştırılması olup, diğer çok çeşitli propaganda edimlerini propagandanın kapsamı içinde görmemektedir. Tanımı, ayrıca, bu kanaat ve görüş yaygınlaştırma ediminin amaçlamnın da incelenmesi gereken bir sorun olduğunu fark etmemiş; özel bir konuşmada tek bir bireyin baska bir bireye görüşlerini ifade etmesi ile, tek bir bireyin tüm bir ulusa kendi görüşlerini yayması arasındaki aymlığı görmezlikten gelmiştir. Propaganda eyleminin en önemli yanı bir kitlesel veya grupsal ikna amacı taşıması oluşu ve siyasal bilimcilerin propaganda ile ilgilenme nedeninin de bu olması yüzünden, bu etmeni görmezlikten gelen veya göremeyen bir tanımın gerçekten yeterli bir çalışmanın ürünü olduğu ileri sürülemez. Fakat bu yetersizliğine rağmen Wreford'un bu tanımı propagandayı sırf ahlâka aykırı olup olmaması açısından değerlendiren eski tanımlamacıların etkilerinden sıyrılabildiği için. sonraki çalışmalarda săglanacak olan gelişmelere ŏncülük etmiş; bu gelişmelerde büyük etkisi olmuştur.

Bir dönem sonra H.D. Lasswell kendi bilimsel yaklaşımı ile siyaset konusuna eğilmis, Wreford'un tanımındaki görüşlere benzer görüşler taşıyan, fakat birçok bakımlardan o'ndan aymlan bir tanım yapmıştır. "Propagande" diyor Lasswell, "belirgin sembollerin manipülâsyonu aracilığı ile kollektif tutumların yönetilmesidir."4 $\mathrm{Ba}$ zı önemsiz ifade değişiklikleri dışında bu tanım Lasswell'in sonraki diğer eserlerinde de temel tanım olduğu için, bunun daha aynntılı olarak incelenmesi gerekmektedir. Propagandayı tanımladıktan son-

4. H.D. Lasswell, "The Theory of Political Propaganda," American Political Science Review, XXI (1927), 8. 627. 
ra Lasswell bu tanımlamasının temelindeki görüşlerini de açlklamaktadır. "“Bir tutum" diyor "belirli değerlendirme kalıplarına uygun şekilde hareket etme eğilimi" olarak ele alınabilir. "Sembolleri" ise birçok yazılarinda "... kelimeler veya resimler ve anlam taşyan vücut hareketleri gibi kelime yerine geçen şeyler" olarak ele alıyor. ${ }^{6} \mathrm{Bu}$ durumda, Lasswell'in propaganda anlaysşı kelimelerin, jestlerin ve benzeri şeylerin, başkalarının düşünce eylemlerini kontrol etme amaciyla, belirli kişilerin siyasal veya diğer sosyal değer standardlarnna uygun düşecek şekilde kullanılmasını içermektedir. Propaganda sorununun özüne yaklaşmış bulunan bu anlayış Lasswell'in propaganda ile eğitimi ayrı ve karşılıklı yerlerde bulunan farklı iki şey olarak kabul eden anlayışına da temel teşkil etmektedir. $\mathrm{Bu}$ nedenle de, bu iki olgu arasındaki ilişki sorununun bütün ayrıntılamyla incelenmesine doğru atılmış ilk adım olarak kabul edilmektedir.

\section{PROPAGANDA VE EĞITIM}

Propaganda ve eğitimin, kanaatların biçimlenme süreci yönünden bakıldığında, birbiriyle öylesine yakın bağlantısı vardır ki, insan bu iki olguyu aynı gibi görmek isteğine kapılmaktadır. Fakat öte yandan bu iki kelimenin akla getirdiği duygusal içerikler birbiriyle öylesine terslik içindedir ki, insan bu iki olguyu biribirinden ayırmak, iki olgunun benzer yanlanndan çok, farklı yanları üzerinde vurguda bulunmak istemektedir. Propaganda ve eğitim olgularını objektif bir yönden incelemek için karşı karşıya olduğumuz duygusal güçlük de buradan oluşmaktadır. Propagandanın eğitime ters bir şey olduğunu öylesine mutlak bir şekilde biliyoruz ki, iki olgu arasında benzer yanlar aramaksızın farklılıklar üzerinde durmamız gerekiyormuş gibi düşünmekteyiz. Gezegenlerin hareketlerini açıklayan eski çağların gökbilim bilginlerinin çabaları gibi, propaganda ile eğitimin farklılıklarını anlatmaya çalışan açıklamalar pekçoktur. Ama gerçekten başarılı ve doğru olanları yoktur. Bunlann gerçekliği ve doğruluğu yarımdır.

Profesör Lasswell bu sorun üzerinde önemle durmuş ve bu konudaki tutumu zaman zaman değişiklikler geçirmiştir. Bir keresinde Profesör Lasswell propagandanın "tartışmalı" ve "karşıt" tutumlar-

5 Ibid.

6 H.D. Lasswell ve D. Blumenstock, World Revolutionary Propaganda (New York: Alfred A. Knopf, 1939), s. 8. 
la ilgili bir sorun; eğitimin ise, kendini, "kabul edilmiş bulunan" tutum ve becerileri aktarmakla görevli sayan bir adım olduğunu ileri sürmüştür. ${ }^{7} \mathrm{Bu}$ tezini ispatlamak için Profesör Lasswell, Sovyetler Birliği'nde Marxist ekonominin ögretim dalı olmasından sonra, Marxist ekonomi öğretmenin kabul edilmiş tutumlarn öğreten bir eğitim niteliği kazandığını söylemektedir. Birleşik Amerika'da ise, kimi yazarlarca bu gibi kabul edilmemiş ve karşıt materyalin öğretilmesi eğitim kabul edilmemekte; Marxist ekonomi öğretimi propaganda sayilmaktadir. (*)

Bu görüşün karşılaştığı güçlük "kabul edilebilir" veya "karşıtca" terimlerinin ne olduğunu açıkca tanımlamakta yetersiz kalmasıdır. Tutumlar çoğunlukla kendilerine uygun tutumları olan kimselerce kabul edilebilir tutumlar; olmayanlarca da "karşıt" tutumlar sayılmaktadır. Yukarda aktarilan örnekte kabul edilebilir tutumlar ile karşit tutumların neler olabileceğini kestirmek zor olmasa da, Birleşik Amerika'da bile pekçok kimse için Marxist ekonominin karşıt sayılması söz konusu değildir. Bu konu üzerinde bundan da derine gitmek ve çeşitli sorular sormak gerekmese, Lasswell'in bu sınıflaması bazı yararlı amaçlar için kullanışlı bir sınıflama sayılabilirdi. Fakat durum böyle değildir. Kabul edilebilir tutumlarla karsit sayılan tutumlar arasında belirli bir farklılığın ortaya konulamayacağı çok ve değişik durumlar olabilir. Örneğin, bir ülkenin kapitalizmden komünizme dönüşümünün hangi aşamasında Marxist ekonomi karşıt olmaktan çlkacak ve Marxist ekonomi öğretimi bozguncu propaganda yerine, resmileşmiş eğitim olarak kabul edilecektir? "Kabul edilebilir" ve "karşıt" gibi son derece sübjektif terimlere dayanan bir tanımlamanın, objektif bir bilimsel çalışma için yararlılığının çok sınırlı olacağı açıktır.

Lasswell'in 1927'deki tutumunu niçin terkettiğini anlamak da zordur. O yıllarda yayınladığı The Theory of Political Propaganda'da "eğitim" terimiyle, imlâ, aritmetik, marangozluk ve buna benzer "tekniklerin kazandırılmasi" edimlerinin ifâde edilmesi gerektiğini ileri sürmüştür. Öte yandan, propagandayı "değerlendirmeye yönelik dispozisyonların ve tutumların oluşturulması" şeklinde; yani, şey'lerle ilgili kanaatlerin biçimlenişi diye ifâde etmiştir.

Tanım olarak oyllarda yaptığı bu tanımlama, tam anlamıyla

$7 \mathrm{Bu}$ tez World Revolutionary Propaganda (1938) ve Propaganda and Promotional Activities'in Giriş'in işlenmiştir.

(*) Bu görüs 1850'lerin Amerikasında; Soğuk Savaş koşullarında görülmüş bir görüştür. Daha sonraki yıllarda bu tür "saçmallklar" kalmamıştır. 
yeterli sayılmasa bile, Lasswell'in sonraki ylllarda benimsediği görüşten çok daha gelişkin ve yeterlidir. İki olgu arasındaki farklılıkla ilgili olarak o ylllarda belirttiği görüşünün değerliliği, aynı eserinde "propagandacl" kişinin tutumu ile, "düşünmeci-tartışmacl" kişinin tutumu arasındaki afrklılığı belirtmesine de dayandırılabilir. Eğitim için temel özellik sayılması gereken düşünmeci-tartışmacı tutum, bir sorunun çözümlenmesi için önerilen bir görüşün; önceden tercih konusu olmuş ve tercih edilmiş belirli bir çözümün bulunmamasını gerektirir. Eğitsel düşüncede amaç gerçeği bulmaksa, düşünen kimsenin eğitimin özüne denk bir tutum içinde kalabilmesi için, ne denli alışılmamış da olsa, gerçeği görmezlikten gelmemesi ve gerçeği baskı altına almaması gerekir. Propagandacının tutumu ise, bunun tersine, bir konuda çözüm aranmasina başlamadan önce belirli bir çözümün saptanmış olmasıyla belirlenmektedir. Diğer bir deyişle, belirli erekleri olan propagandacının propagandaya, bu ereklere eriştirici bir araç gözüyle bakar; propagandayı, zaten önceden kararlaştırmış bulunduğu çözümün "doğruluğunu" ispatlayacak bir arac olarak kullanmak ister.

Düșünmeci-tartışmacının tutumu ile propagandacının tutumu arasındaki farklılığa dayanan bu görüş kabul edilebilir tutumlar ve karşıt tutumlar farklılığına dayanana oranla daha kullanışlı ve gerçekçidir. Fakat Lasswell'in bu tanımında da bazı güçlükler giderilememiştir. Lasswell'in belirttiği gibi, propagandacı teknik becerilerin öğretilmesi ile uğraşmaz; imlâ gibi, aritmetik, ya da mühendislik gibi şeyleri öğretmekle uğraşmaz. Ama uğraşmamasının nedeni, bunların, olağan koşullar altında, propagandacı için ilginç konular olmamasıdır. Kaldı ki propagandacı bu konuların öğretilme tarzından, hangi olgulara dayanarak öğetilmekte oluşlarından, ya da bunları ögrenen sınıfların terkibinden yararlanarak bunları propaganda materyali yapabilir. Tek başına bırakılsalar objektif materyaller olarak kalacak olan dersane materyalleri, istenirse, propaganda taşıyıcısı konular hâline getirilebilir. Örneğin, aritmetik öğrenen küçük çocuklara sayıları belletirken elmalarla veya portakallarla değil de askerlerle veya silâhlarla dört işlem yaptırmak; ya da müzik derslerinde devamlı olarak vatanseverlik şarkıları ögretmek gibi. Burada propaganda etkisini yaratan, bu konuların öğretilme tarzı olmaktadır. Ayın şekilde bir ders kitabinın da propaganda amaçlı mı, yoksa öğretim ve eğitim amaçlı mı olduğunu ilk bakışta anlamak zordur. Bir ders kitabı bu niteliklerden herikisine de aynı anda sahip olabilir. Bir fizik kitabı fizikçiler için düpedüz bir eğitim aracı iken, bir politikacı için politikacının ülkesindeki siyasal sistemin fizik öğ- 
retiminde belirli bir üstünlük taşıdığını gösteren değerli bir propaganda yerne geçebilir. Fakat böyle bir anlayışa dayanılacak olursa, propagandanm bazıları için propagandayken bazılarına göre eğitim olarak görünmesi, ya da aynı kimselerin gözünde bugün propaganda olmayan bir şeyin yarın propaganda gibi görünmesi önlenemez. Bu nedenle, propaganda kavramını tanımlarken "teknik beceriler kazandirilmasinı" unutulmasi ve bunun propagandanın dışında ve propagandaya ters birşey olduğunu ileri sürmek akıllıca bir tutum olmamaktadur.

Bir başka Amerikan yazarının, L.W. Dobb'un eğitim ve propaganda sorunu konusundaki yaklaşımını anlamak için, önce, bu yazarın "öneri" teorisini incelemek gerekmektedir. Bunun için de, önce, Doob'un "tutum" teriminden ne anladığı üzerinde durmak gerekmektedir. Bu terimin önemi Propaganda, Its Psychology and Technique $^{8}$ adlı eserde uzun uzadıya belirtilmiştir. Fakat bu uzun ve bazan sorunu daha da karmaşı kilan değerlendirme ile "tutum" terimini, genellikle kullanilan en bilinen anlamından; yani, insanin belirli bir konumda nasıl hareket edeceğini kısmen belirleyen psikolojik faktörler şeklindeki kaba ve oturmamış anlamından kurtarmak mümkün olamamaktadır.

Doob "uyarı-durum" terimini de bir tutumun oluşumuna yolaçan herhangi birşey ${ }^{9}$ diye tanımladıktan sonra kendisinin "öneri" terimini de şöyle tanımlamaktadır:

"Öneri, uyarn-durumlarm, önceden-varolan ilgili tutumlarn işlemin sonucu olarak uyandirilmaları ile ussal alanda başka ve farklı uyarı -durumlarda oluşmayacak olan yeni bir bütünleşme yaratacak şekilde güdümlenmesi ile meydana getirilir." 10

Öneri fikri, bu bakımdan, bireyin içinde belirli bir soruna karşı belirli tutumların varlığını gerektirmektedir. Bu tutumlar değişmez veya sabit değildir. Fakat "uyarı-durumlar" diye adlandırlan dışsal etkilerle etkilenebilmektedirler. Gören, okuyan ya da duyan bireyde bazı tepkilere yolaçan herhangi bir olgu, rastlan'ti, konuşma, resim veya kitap uyarı-durum sayılmaktadır. Bazı belirli uyarı-durumlar başkaları tarafından kontrol edilebilmekte veya güdümlene-

8 L.W. Doob, Propaganda, Its Psychology and Technique (New York: Henry Holt, 1935), ss. 29-35.

- Ibid., s. 54. Ve bk: Graham Wallas'in "telkin" kavram hakkinda yazdiklar için Bölüm tki.

10 Ibid, ss. $75-76$ ve 89 . 
bilmekte ve bu tür denetimli uyarı-durumlar aracılığı ịle eskiden varolan tutumların yeni tutumların yaratılmasını sağlayacak şekilde değiştirilmesi hảlinde bu işleme de "öneri" denmektedir.

Tutumlar üzerinde herhangi bir etkide bulunamadan uyarı-durum algılandığında, ya da algılamanın sonucunda bireyin tutumları üzerindeki değişimin önceden-varolan tutumlarla ilişkili olmaması hâlinde ise, "önerisizlik" denilen durumla karşılaşılmaktadır.

$\mathrm{Bu}$ teorinin anlaşlabilmesi için izlenecek en iyi yol bir örnek vermektir. Hemen verilebilecek bir örnek olarak, kendinden daha zengin ve esenlikli olanları kiskanan (bunlar önceden-varolan tutumlardır) birini düşünün. $\mathrm{Bu}$ adama da kendisinin yoksulluk içinde olmasının Yahudi asıll mali sermaye sahipleri yüzünden olduğunu ileri süren bir risâle verilmiş (bu uyarn-durumdur) olsun. Adamın önceden-varolan tutumlarına etki eden bu uyari-durum onda Yahudi-karşıtlığı şeklinde (yeni tutum) yeni bir duygunun yaratılmasına yolaçar. Bu süreç de, bu nedenle, öneri diye adlandırılmaktadır.

Diğer yandan, ayni risâle Yahudi olan ve Yahudi-olmayan mali sermayedarlarn ekonomideki yerleri hakkında bilimsel bilgiye sahip bir iktisatçının eline geçmiş olsaydı, bu durumda hiçbir tutum değişikliği oluşmayacağı için, sadece bir algılama olacak, fakat öneri sözkonuu olmayacaktır.

Doob, bununla da kalmamakta, önerileri dolaylı ve dolaysız öneri diye ikiye ayırmaktadır. Dolaysız öneride birey, uyarn-durumun bir bölümü olarak, sunucunun yakın amacını farkedebilmekte; bu nedenle de, bireyin içinde, öneriye ilişkin olduğu kadar sunucuya ilişkin tutumlar da uyanmaktadır. Öneri başarılı olursa, yeni tutumlar sonucunun amacinın anlaşılmasını da içermekte ve ancak böylece sunucunun istediği yönde bir eyleme geçiş yaratabilmekte veya yaratamamaktadır. Dolaysız öneriye verilecek örnek, okuyucunun gazetede gördüğü bir reklâma bakmasıdır. Okuyucu burada bilir ki, reklâmdaki fotoğrafın güzel oluşu, alttaki metnin kusursuzluğu tek bir amaç için düzenlenmiştir : okuyucuya bir otomobil satın aldırmak. Okuyucu bu reklâmın belirli bir reklâmcı tarafından yapılan özel bir öneri olduğunu bildiği için, bu konuda, büyük bir olasılıkla kişisel bir karar alma olanağı bulabilecektir. Okuyucunun mesajı kabul etmesi, kısmen okuyucunun reklâmcıya karşı varolan tutumlarnna bağlı olacaktır. Dolaylı öneride ise sunumcunun amacı örtülü tutulmaktadır. Bu durumda sunumcu kendi ürününü dolaysız olarak salık vermemekte; diğer yollardan yararlanarak ürününden yana tutumlar oluşturmaktadır. Örneğin tıbbì araştırmalar yapan 
bir kurumun yetkililerince " $\mathrm{X}$ " ilàc1 bir terbiyelenmis tütünlerin akciğer kanseri yapmadığının anlaşıldığı yolunda bir açılklama yayınlatılmaktadır. Eğer burada, tıbbì araştırmays yapan kurumun bu araştırmada " $\mathrm{X}$ " ilâcı ile terbiyelenmiş tütün kullanan sigara şirketinden maddî yardım gördüğü açıkca ifade edilmemiş ise, dolaylı öneri sözkonusudur. Doob, sunucunun kişiliği ve amacı örtülü kaldığı için, dolaylı önerinin toplum için daha tehlikeli olduğunu; ayraca, dolaysız öneriye oranla, sunucunun amaçlarının sağlanması bakımından daha yüksek bir başarı şansı taşıdığını ileri sürmektedir.

İşte bu noktadır ki Doob, propaganda koonusunda yaygin olan görüşlerden farklı bir görüşe varmaktadır. Doob'un israrla üzerinde durduğu bu görüş, propagandanın sorunun özünün "tutumları öneri aracllığı ile kontrol altına almak" olduğudur." Önerinin amaçlı olması gerektiği, veya hatta anlaşılması gerektiği propaganda konusu açısindan temel sorun değildir :

Bireyler öneri kullanımı aracılığ ile kontrol ediliyorlarsa... propagandacı bireyler üzerinde kontrol kurmak istemiş de olsa istememiş de olsa, o zaman bu süreç propagandadır. Diğer yandan, aynı bireylerin öneri yardımı ile olduğu gibi, önerinin yardımı olmaksızın da, aynı sonuç yaratılacak şekilde etkilenmeleri mümkün oluyorsa, eğitici ne niyet taşırsa taşısın, bu durumda bir eğitim süreci söz konusudur. ${ }^{12}$

Bu görüş Doob'un ereklenmemiş propaganda teorisinin özüdür. Doob'un bu teorisi propagandayı psikolojik bir olgu durumuna indirgeyerek, propagandayı ahlâkla ya da duygusal içeriklerle ilintili bir olgu olarak görenlerden aymlmaktadir. Bu bakımdan, Doob'un teorisi birçok güçlükler ve karşı çıkılması gereken zayıf yanlar taşımakla beraber, konunun objektif olarak incelenmesi açısından ileriye doğru atılmış önemli bir adım sayılmalıdır.

Açıktır ki, "öneri" süreci hakkında bilgisi olmayan ya da propaganda yapma istek ve bilincinden yoksun pekçok kimseler aracllığı ile de propaganda materyalleri yaylabilmektedir. Örneğin Hitler rejimi sırasında iyi niyetli ve yaptığının bilincinde olmayan pekçok ilkokul öğretmeni öğrencilerine saldırgan milliyetçiliği bu tür propagandalarıyla aşlamışlardır. Fakat bu durumdaki propaganda-

11 Ibid, 8. 80.

12 L.W. Doob, Public Opinion and Propaganda (London: Cresset, 1949), özellikle Bölüm XI. 
nın propaganda amacı taşımaksızın yapıldığını sanmak yanlıştır. Bütün bir Nazi propagandası, çoğu kez kitlelere bilinçsiz ve kasıtsız kimselerin yardımıyla ulaşmıs bile olsa, tamamen savaşçı bir milliyetçilik ve saldırganlık havası yaratmayı hedef alanların eseri olmuştur. Okullardaki öğretmenlerin yaptığını bilmeyen propagandacllar olduğu da söylenemez; öğretmenler siyasal önderlerinin bilinçli propagandalarında kullanılmış bilinçsiz propaganda araçları olmuşlardır. Propaganda, yaptıklarının anlamını fark edemeyen kimseler aracılığı ile yaygınlaştırılmakta olsa bile, bilinçli ve erekli bir eylem sayılmalıdır.

Doob'un görüşüne ters olarak, burada ileri sürülen tez propaganda ile eğitim arasındaki farklılığın özünde propagandanın amaçlı ve bilinçli bir edim niteliğinin bulunmasıdır. Kime ve nerede öğretilirse öğretilsin, birilerine birşeyler öğretiliyorsa ve bu öğretilenler bunların propaganda işlevlerinin bilincinde olan kimselerce yayılıyorsa -ancak bu koşul altında- propaganda saylmalıdırlar.

Propagandanin amaci tutumlari etkileyerek eylemleri denetim altına almaktır. Propagandacı elindeki materyali başkalarına kendisince bilinen yeni bir gerçeği duyurabilmek ya da başkalarını kandirmaktan hissedilen zevki duymak için değil, fakat başkalarına elindeki materyali duyurarak o'nların kendisinin istediği gibi edim ve eylemde bulunmasını sağlamak ümidiyle yayar. Öğretilen konunun kullanılabilmeye hazır bilgilerle sinırlı olduğu eğitimin tersine, propaagndada kullanılan materyalin ve tekniklerin sınırlı olması söz konusu değildir. Bunlar, sonuç almakta taşıdığ̀ sanılan etkinliklerine göre seçilmesi olanaklı değişkenlerdir.

Kısacası, birşeyin propaganda olması için öğrettiği şeyin gerçek olmasına ya da gerçek olmasına inanılmasına gerek yoktur. Birşeyin propaganda olması için, propagandanın öğrettiği materyali kullanan propagandacida okuyucu, dinleyici veya seyirci kitlelerde belirli durumlara karşı o'nun istediği yönde tutum değişikliği yaratma amą̧ ve isteğinin bulunmaș yeterlidir. Propagandada öğretilen şeyler ile, bu şeyler aracılığı ile etkide bulunulmak istenen tutumlar arasındaki ilişki açık ve görülgen olabileceği gibi, saklı da olabilir.

Doob'un açıklamalarına dönecek olursak: O'na göre önerinin ortaya çıkışı bir uyarı-durumunun "önceden-varolan, ilgili tutumların uyandıralması sonunda" yeni tutumların yaratılmasını sağlayacak şekilde güdülenmesine bağlıdır. Buna ters olarak da, önce- 
den-varolan tutumlarda bir değişiklik olmaksızın uyan-durumun salt algılanmasının sonunda -ise, öneri oluşmamaktadır. Böylece, Doob'un da kabul ettiği gibi, herhangi bir kimse için öneri (dolayısıyla, propaganda olan) bir şeyin, bir başkası için de propaganda olması gerekmez. Bu bölümde daha önce verilen Yahudi-karşıtı risâle örneği bu noktayı açıklamakta yararlı olacaktır. Böyle bir anlayışla propagandanın bilimsel bir açıdan belirlenmesi veya derecesinin anlaşılması çok güçtür. Bunun nedeni ise, sorunu bilimsel bir görüşle inceleyen bir gözlemcinin, propagandayı algılayan bütün bireylerdeki tutumların değişip değişmediklerini sınaması gerektiğidir. Doob'un görüşüne karşı yapılacak en ciddi itiraz da bu açıdan yapılmaktäır. Propagandanın varlığını anlamaktaki ölçü "öneri" olmakta; "önerinin" ardinda ise, "önceden-varolan tutumların uyandirılması" bulunmakta; fakat sözü edilen, önceden-varolan tutumlann bulunup bulunmadığını kestirebilmek için ne yapılabileceği; ya da bu tutumlarda bir değişme olmuşsa; bunun ne çapta bir değişme olduğunu anlamak için, bazı belli bireyler üzerinde yapılabilecek klinik gözlemleri dışnda, nasıl bir ölçü kullanılabileceği ve nasıl bir yol izlenebileceği belirtilmemektedir. Doob'un teorisine dayanarak ne Einstein'in görecelik Teorisinin eğitim olduğunu, ne de Hitler'in söylevlerinin propaganda olduğunu ileri sürmek olanağı vardır. Cünkü herşey bunları alglayan bireye dayandırılmış bulunmaktadır. Doob'un propagandayı tanımlaması, sonunda, tek tek bireylerin alımcl olarak taşıdıklan yeterliğe bağlı olmaktadır. Diğer bir deyişle, propaganda bir süreç olarak değil, bir etki, bir sonuç olarak tanımlanmış olmaktadır.

Daha sonraki yazılarında Doob kendi görüşünce de psikoloji açısından yetersiz kaldığı için, propaganda ile eğitimi ayırt etmekte "öneri" kavramını terketmiştir. ${ }^{13}$ Doob, bu kavramin öneri ile veya önerisiz olarak öğrenilen ve eğitim süreci içinde yeralmayan toplumsal adetlerin ve göreneklerin varlığını içermediğini ifade etmiştir. Ancak, bu sonraki yazılarında Doob'un ileri sürdüğü yeni görüş propagandada dağıtılan materyalin ahlâkçı bir açıdan değerlendirilmesine dayandığı için, ilk görüşünden' daha da başarısız kalmıştır. Eğitim, o'na göre, “... bilimsel sayılan veya belirli bir dönemde kalıcı değer taşıdığı kabul edilen bilgi ve becerilerin yazandırılma$\mathrm{sl}^{\prime},{ }^{14}$ propaganda ise "... bilimsel sayılmayan ya da belirli bir dönemde toplumda kalıcı değerde bulunmayan amaçlar için bireyle-

13 Ibid, s. 237.

14 Ibid, s. 240. 
rin davranışları üzerinde denetim ve hakimiyet kurmạk veya kişiliklerini etkilemek girişimidir." 15

Bu siniflamaya yaplabilecek en önemli itiraz, bu sınfflamanın, genellikle propaganda olarak kabul edilen faaliyetlerin tamamin kapsayamadığı şeklindedir. Gerçekten, propagandacı sayılabilecek ve kendisi de propaganda faaliyeti ile meşgul olduğunu kabul eden biri bilimsel nitelikte bir materyali propagandacıya göre propaganda saylabilecek bir amaçla kullanmaktaysa, bu durumda, bilimsel bir materyalin dağıtılması ve yayılmasının da propaganda olarak kabul edilmesi gerektiği ileri sürülebilir. Bu tür materyallelrin propagandacılar tarafından kullanılması Birinci Dünya Savaşı yıllarnndaki propaganda etkinliklerinin incelenmesi ile açıkca ortaya çıkmaktadır. Günümüz propaganda tekniklerinin incelenmesi de bunun çok yaygin olduğunu göstermektedir. Örneğin; Birleşik Amerika Devletleri de, Amerika'nın teknik ve sınaî alandaki üstünlüğünden propaganda alanında ne denli geniş bir şekilde yararlanabileceğini anlamış bulunmaktadır. Sovyetler Birliği'ne karşı Birleşik Amerika'nın itibarını yüksek gőstermeyi de içeren Soğuk Savaşın bir uygulaması olarak, Amerikan hükümetleri özel şirketlerin yabancı ülkelerin basın organlannda yayınlattıkları ticarî reklâmlara malî yardımda bulunmayi; gelişmekte olan ülkelere Amerikan patentlerinin kullanılması için yardımda bulunmayı ve kolaylık göstermeyi, eğitim ve teknik alanlarda uzman ve teknisyen göndermeyi, uzmanlık çalışmaları için bu ülkelerden ilgilileri ülkeye getirtmeyi gelenek haline getirmişlerdir. ${ }^{16}$ Bütün bunlar, kısmen, propagandaclar propaganda yapmak için kullandıklarından dolayı, propagandadırlar. Fakat Doob'un görüşüne göre değerlendirme yapllacak olursa, patent kullanımına izin vermek "bilimsel sayılabilecek nitelikte bilgi aktarmak" diye; yani, eğitim olarak kabul edilmek gerekecektir.

Doob'un kendisi bile, yaptığı tanımlamanın kendisinin bütün bir savını ne denli geçersizleştirdiğini kavramıs değil. Ama gene de tanımlamasının bazı güçlükleri aşamadığını kabul etmektedir. Örneğin, eğitim ile propaganda arasındaki farklılığı belirlemek isteyen bir kimsenin "bir konu hakkındaki bilimsel bilginin o konudaki durumu" iyi değerlendirmesi gerektiğini belirten Doob bu durumdaki

15 R.E. Summers (ed.), America's Weapons of Psychological Warfare, IThe Reference Shelf 23 (4)), (New York: Wilson, 1951), s. 38.

16 Ceşitli sinıflamalar hakkında yapılmıs bir araştırma için C.H. Wooddy'nin "Propaganda and Education" yazıs1, Bk: The Annals of the American Academy of Political and Social Sciences, CLXXIX. (1835), ss. 227-238. Bazılar sonraki sayfalarda da tartışllyyor. 
bir kimsenin düşünürken "kullandığı değer yargısının farkında olması gerektiğini" belirtmektedir. Lysenko'nun teorilerine karşı genetic bilginlerinin ISI ve ihtiras kavramlan ile itirazda bulundukları, veya fizikçilerin quantum teorisinde determinizmin olamayacağı yönünde felsefe yapabildikleri hatirlanacak olursa, bu gibi hissi olmayan ve laboratuarlarda deneyleri yaplabilecek konularda bile neyin bilimsel bilgi saylabileceği sorunu çözümlenememişken, siyaset ve ekonomi gibi konularda bilimsel bilgi saylabilecek bilgileri belirlemekte herkes için geçerli ölçülerin bulunabilmesinin zor, hatta olanaksız olduğu açıktır. Doob propagandayı tanımlarken öyle kavramlar kullanmıştır ki, bu kavramların kendileri bile açık bir anlama sahip değildir. Bu bakımdan, yaptığı tanımın yeterli bulunabilmesi söz konusu olamaz.

Propaganda ile eğitim arasındaki farklılığın ne olduğunu belirtebilmek için daha başka pekçok tanımlar da yapılmıştır. Bunlarnn bazları siyasal bilimcilerin kendi savları içinde ve onlara denk düşecek şekilde yapılmış ve bu nedenle de genel olarak mantık açısından geçerlilikten yoksun kalmışsa da günümüzde toplumumuzda yaygin siyasal ve sosyal düşüncelerin ürünleri olduklarn için bu tanımlar üzerinde de durmamız gerekmektedir. ${ }^{17}$

"Eğitim çocukluk dönemindeki bireylerin yetiştirilmesiyle, propaganda ise yetişkinlerin davranışlarının etkilenmesi ile ilgilidir," 18 ya da "eğitim okulda ögretilenlerle, propaganda ise okulun dişında ögrretilenlerle ilgilidir"'19 şeklindeki afaki görüşler o denli yetersizdir ki bunların eleştirilmesine bile gerek yoktur. Fakat bazlamnın geçersizliğini belirtebilmek için üzerinde durmak gerekmektedir.

Siyaset pratiğinde "propaganda" kavramının karşı tarafın "sahteciliğini" ve "yalancılığını" ifade etmek için kullanılması çok yaygın olduğundan, bu aşağılayıcı kullanışı yüzünden halkın gözünde "propaganda" ile "yalanın" aynı şeyler gibi görünmesi önlenememektedir. Fakat objektif bir değerlendirme yapilırsa propaganda ile yalanın aynı şeyler olmadığı hemen anlaşılacaktır. Savaş döneminin propaganda faaliyetleri üzerinde yapılan incelemeler göstermiştir ki, propaganda olarak yapılan ve karşı tarafın yalanları sayılması gereken pekçok şeyler reddi mümkün olmayan gerçeklerden oluşmuşlardır. Diğer yandan şunu da kabul etmek gerekir ki, herkesin eğitim diye kabul etmekte olduğu şeylerin pekçoğunun reddi mümkün

17 Ibid, 8. 227.

18 Ibid, 8. 228.

18 Ibld, 8. 231. 
olmayan gerçeklere dayandıkları söylenemez. Özellikle, tarih ve ekonomi gibi sosyal bilimlerde ve siyasal bilimlerde yapılan tartışmalar ve öğretimde olgularnn kişisel bir yorumlamadan geçerek anlamlandımlması önlenememektedir. Örneğin, uygulamanın da gösterdiği gibi, Amerikan Yüksek Mahkemesi veya Ingiliz "welfare state" anlayışı gibi konuların derslerde işlenişinde öznel değerlendirmelerden uzak kalmak mümkün olamamaktadır. Tarih öğretimi de, büyük ölçüde, olguların açıklanmasına ve değerlendirilmesine dayanmakta; kendileri de tartışma götürür nitelikteki bu değerlendirme ve açıklamalar tarihteki olguların kaydı ya da izi bulunamayan nedenleri yahut da sonuçlar için yürütülen usavurmalara ve varılan yargilara temel teşkil etmektedir. "Olgu" ve "tasarlanım" gibi terimler de, bu nedenle, herhangi bir tanımda kullanılabilecek anlam açıklığından ve kesinliğinden yoksundurlar.

Propaganda ile eğitimi biribirinden ayrmakta, bazan, öğretilen şeyin ne olduğu değil de öğretme işleminin ereği kriter olarak kullanılmaktadır. Bu durumda eğitim "tüm topluma hizmet etmek saiki ile yäpılan;" buna karşılık, propaganda "belirli bir grubun çıkarlamun sağlamak için yapılan" bir öğretme sayılmaktadır. Bu tür bir yorumlama, herbiri şu ya da bu grubun değil de tüm bir toplumun yaran için hareket ettiğini ileri süren rakip propagandacıların gerçek durumlarını dikkatle değerlendirecek uyanıklıkta bulunmayı gerektirmektedir. Kald l ki, "toplumun yaranna" terimi de nesnel (objektif) bir terim değil, herkesin kendisine göre değerlendirebileceği bir terimdir. Locke ve Rousseau'dan beri bilinen bir gerçektir ki, toplum yararına denen şeyler, pratikte, sayıca çokluğu teşkil edenlerin ya da kendisini çoğunluk olarak kabul ettirmesini bilen bir azınlığın yararına olmaktadır. "Toplum yararına" ölçüsüne dayanarak yapılacak bir sınıflamada, açıktır ki, "bizden yana" olanların eğitim; "karşı taraftan" yana olan fikir ve kanaatların yayılması ise propaganda saylması gerekecektir. Gerçeleten, en iyi-niyetli kimselerin bile, kendilerine karşı olan grupların görüşlerinde toplum yararına birşeyler bulunduğuna inanabilmesi güç olmaktadır. Böyle bir tanimlama biçimi, sonunda, bizden olmayan herşeyin propaganda sayllmasi gerektiği gibi bir saçmaliğa dönüşmektedir.

Incelenmesi gereken son bir görüş de eğitimin toplumsal kalıtımı Isocial inheritance : önceki kuşaklardan aktarlan bilgi, inanç, görenek, beceriler bütünül kuşaklara aktarmak; propagandanın ise, sosyal sistemi değiştirmek amacıyla insanlara bir doktrin aşılamak için yapıldı̆̆ını ileri sürenlerinkidir. Toplum yararı'nı bir kriter olarak kullanan tez gibi, bu görüșün zayıf yanı da bu ikisi arasında 
kesin ve herkesin kabul edebileceği bir sınurn bulunmamasıdır. Toplumsal kalttım diye gösterilebilecek değişmez ve durağan olgu kümeleri ve teoriler mevcut olmadiğına göre, sosyal kalıtımımızın kapsaminda ne gibi öğelerin bulunduğunu ve bunlardan hangilerinin gelecek kuşaklara aktarılması gerektiğini kararlaştırabilmek gerekmektedir. Ne var ki, böyle bir konuda insanların bir görüş birliğine varabileceklerini ummak budalalık olacaktır. Toplumumuz durgun ve kısir bir toplum olmadiğı sürece, toplumumuzun gelişmesi için yapılan her programın bazı bakımlardan geçmiş günlere borçlu olacağı, bunun için de sosyal kalıtımın bir kısmı saylması gerekeceği açıtır. Örneğin, günümüzde hem Sosyalist hem de Kapitalist topIumlar Liberal-sınai devrimin mirasçısı olduklarını söyleyebilmektedirler. Aynı şey Rodezya'daki beyaz sömürgeciler ile, Nijerya'daki Afrika milliyetçileri için de söz konusudur. Hatta öyle ki, toplumsal kalıtımımızın bazı yanlarını değiştirmeksizin sürdürmek isteyenler ile, bunları değiştirmek isteyenler arasında bile tam bir sınırlama yaplamamaktadır. Bunun nedeni, en tutucu topluluklarda bile status quo'nun gerçek hayatta varlığı söz konusu edilebilecek bir olgu değil, sadece bir slogan oluşudur. Burada sorun durgunluğa karşı değişim sorunu değil, değişimin yönü sorunudur.

"Toplum yararı" ve "toplumsal kalıtımın aktarılması" ilk bakısta hoş gözüken ifadelerdir. Bunlar, iyi ve olması gereken biçimdeki kendi toplum anlayışımızı ifase edecek biçimde kendimize uydurmamız kolay ibarelerdir. Neyi ve nasil istiyorsak o'nları ifade ettirmekte kullanabileceğimiz ibarelerdir bunlar. Fakat bilimsel bir tanım için temel alınabilecek değerde değildirler; çünkü, belirlenmis durumlara uygulanmak istendiğinde bunların, insanların kendi kafalarının derinliklerinde saklı önyargılarını gözlerden saklamak için kullanılan parlak "kostümler" oldukları ortaya çlkmaktadır.

Elealdığım bu ve bu kadar önemli olmayan diğer teorilerin incelenmesinden, eğitim ile propaganda arasındaki ilişki hakknda bazı sonuçlara varmak mümkün görünmektedir. Çok yaygın olan inancın tersine, bu iki olgu biribirinden sanıldığl kadar farklı değillerdir. Gerçi herikisinin de kendilerine özgü özellikleri vardır. Ama herikisinde de aynı olan edimler ve işlemler de çoktur.

Nitekim, normal olarak bir propagandacı için önemli olan, eğitimin temel edimleri sayılması gereken becerilerin öğretilmesi ya da Lasswell'in deyişiyle "tekniklerin kazandırılması" değilse de, bu konuda eğitimci ile propagandacı arasında çok katı bir ayrım yapmak da doğru değildir. Propagandaç da herhangi bir eğitim prog- 
raminin hemen her yanından propaganda amaciyla yararlanabilir. Diğer yandan, lehte tutumlar yaratmak amaciyla, doğru bilinen ama gerçekte birgün yanlışlığı ortaya çıkacak şeylerin bilinçsiz bir şekilde yayılmasına aracilık yapan bir eğitim programı da, aslında, eğitimin özüne ters düşecektir. Çünkü böyle bir sözde eğitimin "gerçek" olduğunu söyleyerek öğrettiği şeylerin gerçekliği, yaşanılan o dōnemin "bilgileriyle" belirlenmiş kısıtlı bir gerçekliktir. Eğitimde kriterin objektif bir gerçeğe dayanmanın olacağı da söylenemez. Çünkü buradaki "gerçek" de ancak belirli bir kanaatın sahiplerince "gerçek" olma niteliği taşımaktadır. Bu bakımdan geçit törenleri, üniformalar, posta pulları, askeri araçlar vb. gibi propaganda örnekleri, okul yaşantısına birçok yönlerden olumlu katkıda bulundukları hálde, bunların eğitimle bağlantıları ancak dolaylı bir bağlantı niteliğindedir.

Fakat bu uç durumlar arasında yeralan ve hem eğitim hem de propaganda faaliyetlerinin kapsamina girebilen pek çok faaliyetler vardır. Propaganda; kanaatları etkileme girişimidir; ama pekçok alanlardaki eğitim, özellikle sosyal bilimlerdeki eğitim olguların kendilerinden çok olgular hakkındaki kanaatlarla ilgilenmektedir. Bu eğitim konularının kendi doğaları gereği iş değer yargılarının ifade edilmesinde düğümlenmekte; sonuç olarak da, bu konuları öğretenler eğitime ayırdıkları zamanın büyük kısmını, başkalarını kendi yorumlamnın doğruluğuna inandırmak için harcamaktadırlar. Bu tür kanaat açıklamalar, bunların objektif bir gerçeklik ve değerlilik taşıdığına inanan iyi niyetli kimseler tarafından yapılıyorsa, eğitim sayılmaktadır. Fakat bu kanaat açıklamalar, bunları duyanlarda kendilerine karşı belirli tutumların uyanması amacıyla yapılıyorlarsa, aynı zamanda propaganda niteliği de kazanmış olmaktadır. Siyaset ve iktidat dersi verenlerin çoğunda bu istek veya amaç az veya çok vardır. Fakat bunun böyle olması bu kimselerin içtenlikle eğitim yapmakta olmalarını kabüle engel sayılmamalıdır.

Bu konudaki görüş birkaç cümle ile özetlenebilir. Eğer öğretilen materyalin gerçekliğe sahip olmadığı [doğru olmadığıl biliniyor, ama bilinçli olarak kandırma amacıyla bu materyalin öğretilmesine devam olunuyorsa bu eğitim değil, propagandadır. Diğer yandan, eğer öğretilen materyalin doğru olduğuna dair dürüstce bir inanç taşınıyorsa bu işlemin eğitim, propaganda veya herikisi birden sayılması mümkündür. Gerçek [doğru] olup olmamasından apayrı olarak, eğer amaç bireylerin tutumlarını belirli yönde etkilemekse, işlem propagandadır. Kısacası, propagandayı eğitimden ayırmak için yapılan açıklamaların çog̣u, bu iki olgunun farklı kriterlerlerle ölçül- 
mesi gerektiğini kavrayamadıkları için başarısız kalmışlardır. Eğitimde ayrıştırıcı standard, sağlanabilen [bilinen] bilgilerin ışığında, eldeki materyalin gerçek ve doğru olup olmamasıdır. Propagandadaki standard ise, ögrretilen materyalin ne amą̧ için öğretilmekte olması; bir diğer deyişle, öğretimdeki amaçtır. Amaç, doğru ve gerçek olduğuna inanılan bir materyalin öğretilmesi işlemi ile sağlandığı takdirde ise, işlem aynı anda hem eğitim hem de propagandadur.

\section{GERÇEK VE USSALLIK}

Propagandanın aslında aldatıc ve irrasyonel bir ikna biçimi olduğuna dair halk arasında yaygın olan inancın kökeni, herşeyden önce, "bizim" enformasyon ve haber servislerimizin "o'nları" servislerinden farklı olduğunu; "o'nlarnkinin" propaganda ve düzmece haber ve enformasyon yaymakla görevli kuruluşlar olduğunu benimseten siyaset pratiklerimize dayanmaktadır. Soruna yakından bakıldığında "bizimki" ile, "o'nlarınki" dediklerimiz arasında farklllıklardan çok benzerlikler olduğunu görsek bile, bu yanlış inanctmizdan vazgeçememekteyiz. Propaganda ile aldatmacayı ve irrasyonel iknayı aynı şey sayan bu yaygin görüşün ikinci nedeni ise, Birinci Dünya Savaşindan sonraki ylllarda, "bizim tarafin" da gerek düşmanlarımızı gerekse dostlarımızı irrasyonel güdümlemelerle yöneltmek için ne denli yalanlara başvurduğunun anlaşılması üzerine, insanların moral ve entellektüel bir şok geçirmiş bulunmalandir.

James Bryce gibi parlak bir bilim adamı bile, 1921 yılında yazdığı yazılarında savaş propagandacılarına karşı girişilen eleştirileri kayıtsız ve şartsız kabullenmiş; propagandayı "aldatmaca ve gerçek-olmayan şeylerin basılı haberleşme araçlarıyla yayınlamak ve şiddete ortam hazırlamak"20 diye tanımlanmıştır. Bryce'ın anlayışına göre, propaganda, esas itibarıyla, ahlâksızca birşeydir ve gücünü kamuoyunun zayıflığından almaktadır. Propaganda çok uzmanlaşmış bir sanat hâlini aldığından bu işle uğraşanlar aldatıcı ve tekyanll bildirimlerle, gerçekleri kendi başlarina bulma yeteneğinden veya isteğinden yoksun kimseleri "aldamakta ve kötü yöne yöneltebilmektedirler.

Propagandanın yalancılıkla eş olduğu görüşü, önçe, 1918'i izleyen yıllarda ortaya çıkmışsa da, savaş günlerinin propagandacılarının neleri kullandıkları dikkatle incelendiğinde, propaganda ile yalancı-

20 J. Bryce, Modern Democracies (New York: Macmillan, 1921), II, s. 505. 
lık arasındaki aynılığın fazla özsel olmadığı anlaşılmaktadır. Üçüncü Bölümde savaş propagandası incelendiğinde görülecektir ki, her propagandanın yalan ile eş tutulması doğru birşey olamaz. Elbette ki, propagandacilar yalan söyler. En azından, baski altında oldukları için, doğrudan çok yalan söylerler. Propagandacıların çalışmalarının toplam olarak yarattıkları sonuç da bir kandırmadır. Gerçeklere dyandıklarında, doğru söylediklerinde ise, yarım kalan bu doğruluklar, halkın, hedef-kitlelerin önünde doğru söyleyebilecekleri izlenimini yaratma amacin tassmaktadır. Propagandacilarin yaptzklan propaganda, ilke olarak, ne sadece gerçeğe ne de sadece yalana değil, fakat ikna edici olma amacına dayanmaktadır. Propagandacılar gerçekleri olduğu kadar yalanlar da kullanmaya hazırdurlar. Hangisini kullanacakları kitleyi ikna etmekte hangisinin daha etkin olacağı konusunda varacaklar karara bağlıdır. Propaganda ile yalanı eştutarak bu noktayı görmezlikten gelen bir propaganda teorisinin, bu nedenle, yetersiz saylması gerekir.

Propaganda ile yalanı aynı şey sayan kolaya kaçma eğiliminin sonucu olan bu görüşü karşlamak için izlenecek en etkin yol gerçekte propagandacının neler yaptığını göstermektedir. Fakat olgulara başvurma yoluna gitmeksizin de burada incelenmesi gereken daha teorik nitelikte bazı görüşler bulunmaktadır.

Bir kere, herşeyden önce, neyin yalan, neyin doğru olduğunu söylemek zordur. Çünkü gerçeğe dayanmayan sözlerin hepsi yalan olmayabilir. Bir şeyin yalan olması için temel üç öğe şarttır : materyal gerçeklikten yoksun olmali; bunun gerçeklikten yoksun olduğu biliniyor olmall; ve kandurmak için söyleniyor olmall. Fakat yanyana geldiğinde yalanı oluşturan bu üç öğenin pratikte farkedilmesi çok güçtür. Birçok halde insan masumca söylenen gerçek dışı şeylerle kasten ve bilinçli olarak söylenen yalanlar biribirinden ayıramaz.

$\mathrm{Bu}$ tür belirsizliğin yaratacağı sonuçlar II. Dünya Savaşındaki hava muharebelerine ilişkin haberlerde açıkca görülmüştür. 1940 yllı Temmuz ayından Ocak ayına kadar süren İngiltere Savaşında İngiliz radyo ve basını, İngiliz hava savunması makamlarnnca doğruluğu resmen kabul edilen Alman uçak kayıplarını ayrıntılı olarak vermişler; fakat sonradan bunların doğru olmadığ rının çok aşırı ölçüde abartılmış olduğu anlaşılmıştır. Buradaki gerçek-dışılık, düşman uçağı tahrip ettiğini söyleyen kimselerin beyànlarının resmî ifadelerde temel alınmasından oluşmuştur. Avcı uçaği pilotlamndan ilsisi-üçü aynı Alman uçağı için ayrı ayr bildirimde bulunmuşlar; AvCı Filosu komutanının havada vurduğu bir uçak 
aşağıdaki uçak-savar birliklerince de bildirim konusu olmuş; vuruldu, denize düştü denen bir uçağın denizi aşıp Fransa'ya gitmiş olabileceği, tamir görüp tekrar görevlendirilebileceği unutulmuştur. Bütün bu gerçek-dışı bildirimlerin toplam etkisi çok şaşırtıcı olmuştur. Sadece 1940 Eylül'ünde İngilizler 1.108 Alman uçağı düşürdüklerini açıklamışlardır. Daha sonra kontrol edilen Alman kayıtları bu rakamın sadece 582 olduğunu göstermiştir. Dört aylık tüm savaş döneminde İngilizler 2.698 uçak düşürdüklerini söylemişlerdir. Almanların kaybı gerçekte 1.733 uçak olmuştur. ${ }^{21}$

$\mathrm{Bu}$ örnekten anlaşıldığı gibi, bütün bu rakamlan veren sorumluların yalancılık yaptıklarını söyleyemeyiz. Çünkü büyük oranda bu insanlar da iyi niyetle ve söylediklerinin doğruluğuna inanarak bu rakamları vermişlerdir. Ne var ki, İngilizler Almanya'yı uçaklarla bomzalamaya başladıktan ve İngiliz hava hücumlar yoğunlaştıktan sonra, aynı nedenlerle Almanlar İngilizlerin uçak kayıpları hakkında gerçeğin çok üstünde rakamlar vermeye başladıklarında, bu kere de Ingilizler Almanları yalancılıkla sıç̧lamışlardır. Burada görülen eğilim, "biz" birşey söylediğimizde söylediğimiz şeyin gerçek-dışı olduğu anlaşılırsa bizimkinin iyi niyetle yapılmış bir yanlışlık; fakat "karşımızdaki" aynı şeyi yaparsa o'nun yaptığının yalan sayılması seklindedir. ${ }^{22}$

Bu konuda bir başka güçlük bir yalanın, dolayısıyla propagandanın tanınıp fark edilmesi için, mesajı alan taraftaki insanların bu konuda bilgi sahibi olmaları gerektiğidir. Birçok durumlarda, biJinçli olarak söylenen yalanlar da dahil olmak üzere, gerçek-dışı bildirimlerin hiçbir dirençle karşılaşmadıkları, bu tür bildirimlerde mesajı alan kimselerin mesajı gönderen taraf kadar bilgi sahibi olmamaları yüzünden, bunların propaganda niteliği taşımalarının anlaşılmadığı bilinmektedir.

İster savaş zamanında isterse barış zamanındaki ülke-içi siyasal hayattaki faaliyetleri itibariyle olsun, propagandaclarin neler yaptıkları incelendiğinde, çoğu propagandacının hiç değilse zaman zaman doğru söylediği anlaşılmaktadır. Fakat bunun da dışında, yukarda tartışılan sorunlar da göstermektedir ki, "gerçek" ve "irrasyonellik" gibi kavramların pratikteki kullanım güçlüğü propaganda ile eğitimi biribirinden ayırt etmekte bu terimleri geçersiz kılmaktadir.

21 W. S. Churchill, Their Finest Hour (Boston: Houghton and Mifflin, 1949), s. 339.

22 F.E. Lumley, "The Nature of Propaganda," Sociology and Social Research, XIII (1929), 8s. 315324. 


\section{ÖRTÜLÜ PROPAGANDA}

Propaganda konusunda en önemli yazarlardan olan F.E. Lumley incelemelerinde propagandanin bir tehlike ve tehdit oldugu inancinı kendisine temel almıştır. Bu bakımdan da, ancak bu görüşünü haklı kllan propaganda teorilerini değerli bulmak durumunda kalmıştır. Bununla beraber, kendi öznelci tutumuna rağmen, propaganda konusunda en yaygın düşünceleri en tutarlı şekilde biraraya getirip sunan da Lumley olmuştur.

Lumley, Birinci Dünya Savaşının propaganda konusunda geçirdiği tecrübelerin yolaçtığı olguları ve bunların sonuçlarını 1920'lerde incelemeye; propagandayı sosyolojik ve psikolojik açıdan açıklamaya çalışan az saydaki öncülerdendir. Lumley'in ilk tanımlaması $1929^{23}$ yılında olmus; propagandanın "sonul yargıların yaygınlaştırılmasından" ne fazla ne de noksan birşey olmadığını ileri sürmüştür. Bu tanım son derece yoruma açıktır. Ama olmakla belirli bir propaganda türü için en uygun tanım da bu tanım olmuştur.

Yeniden propagandanın doğası ile ilgili incelemelerine başladığında, The Propaagnda Menace ${ }^{24}$ adlı eserinde Lumley tanımının propagandanın en önemli özelliklerinden birini dile getirdiğini, fakat bu kavramın anlaşılması için gereken diğer birçok özellikleri dile getiremediğini; bu bakımdan da, tanımının yetersiz kaldığını farketmiştir. Bunun üzerine yaptığı ikinci tanım ise, ilk tanımından da bulanık bir tanım olmuştur:

Propaganda, (1) kökeninin veya kaynağının; (2) arkasındaki çıkarların; (3) işlendiği yöntemlerin; (4) yaydığı muhtevanın; (5) kitlede yarattığ 1 etkilerin; bunlardan birinin, ikisinin, üçünün, dördünün, veya beşinin saklı tutulması ile tanımlanabilecek bir işlemdir.

Bu tanımlama ve bu tanımlamasını ispatlamak için kullandığı deliller Lumley için bir mantık tuzağı olmuştur. İleri sürdüğü varsayımdan (propaganda örtülü yollarla yaratılan etkidir) çıkardığı belirli özellikler (yukarda belirtilen saklı özellikler), sonunda, ilk varsayımı ispatlayan 'olguların saptanmasında kullanılmakta; varsayımı ispatlamaya yaramaktadir.

Lumley için propagandayı yapanın kendi kişiliğini sakladığı propaganda türü için örnek vermek güç olmamıştır. Fakat propagan-

23 Yayın tarihi 1833.

24 F. E. Lumley, The Propaganda Menace (New York: Century, 1933), s. 44. 
dada kökenin ve propağandayı yapanın kişiliğinin saklı tutulması neyin propaganda olduğunu saptamakta esas alınacak olursa, nerede birşey söylenmiş, ama bunu ilk söyleyenin kim olduğu unutulmuşsa orada bir propaganda işleminin bulunduğunu kabul etmek gerekeceği açıktır. Bu durumda ise, bütün atasözlerinin, sahibi unutulmuş şiirlerin, halk türkülerinin çoğunun ve ilâhilerden güzel olanlarının, nerede ve ne için kullanılmış olurlarsa olsun, sahipleri belli olmadığı için propaganda sayılmalarn gerekecektir. Böyle bir propaganda tanımı propaganda kavramını anlatan sıradan tanımlardan bile öylesine uzaktır ki, üzerinde fazla durulmaya bile değmez.

Buradaki bulanıklik, belki de, bir dereceye kadar Lumley'in "sakli tutulmak" deyiminin belirli bir anlam taşımamasından meydana gelmektedir. Eğer Lúmley'in bu terimle propagandanın alanı daralacak; ancak, kendini gizlemesini bilen ve becerikli kimselerin yaptığı propagandalar propaganda sayılacaktır. Bunlar, görünüşteki kökenleri hiç kuşku yaratmayan; bu nedenle de propaganda oldukları hiçbir zaman anlaşılmayan türden propagandalardır.

Aslında Lumley'in sözlerinin arḍ̂nda saklı düşünce, birşeyin propaganda olmasının propagandayı yapan kimsenin bilinçli olarak kendi kişiliğini gizli tutmasına bağlı olduğudur. Bir süre sonra propagandacının kişiliği ortaya çıacak olsa bile, bu durum değişmemektedir. Fakat bu tür bir yaklaşım da güçlüklerle karşı karşıyadır. Örneğin. Londra'da yayınlanan Daily Mirror gazetesinde karikatür serileri çıkan Vicky isimli sanatkâr, sırf gerçek ismini kullanmadiğı için propagandacl $\mathrm{ml}$ sayılacaktır? Yoksa, eserlerinin devamlı olarak belirli bir gazetede yayınlanmakta olması yüzünden, kişiliğini gizlemediğini kabul etmek mi gerekecektir? Aynı şekilde, Washington Post'un karikatüristi olan ünlü Herblock'un eserleri, bu gazeteyle ilgili olmaksızın yayımlansa propaganda mı sayılacaktır. Görülüyor ki, "ben bunun nereden geldiğini, kimin tarafından yapıldığını bilmiyorum, öyleyse bu bir propagandadır" demek kolay değildir. Propaganda konusunu inceliyecek olan bir kimsenin, bir propaganda eyleminde işlemin arkasındaki kimsenin kişiliğinin bilinçli olarak gizli tutulması durumu ile işlemin ardındaki kimsenin kişiliğinin bazı belirli hâllerde ve ancak bazı kimselerce bilinememesi durumunu biribirine karıştırmaması gerekir.

Lumley'in "saklı tutulan" özellikler arasında belirttiği diğerleri de bu aynı açıdan eleştirilebilir. Bunların herbirinde de, ilgili özelliğin kasten mi yoksa istemeden mi gizli tutulmakta olduğu sorusu 
ile karşılaşılacağı açıktır. Propagandacının, örneğin, propagandadaki çıkar konusu ile olan ilişkisini açıklaması her zaman gerekmeyeceği için her propagandanın, sırf yapan bu ilişkisini belirtmedi diye. propagandacının kişiliğinin saklı tutulduğu bir edim sayılmasına imkân yoktur. Bu gibi durumlarda, bazan, propagandacının propagandadaki çıkar konusu ile bylesine yakın ilişkisi vardır ki, herkesce bilinen veya bilinebilecek olan bu çlkar ilişkisini her propaganda ediminde açıklamak propagandacıya haklı olarak gereksiz görünmüs olabilir. Ayrıca, birçok durumlarda propaganda yapanlar hangi çkarla ilişkili olduklarını bilmezler; bilmedikleri için de açıklayacak birşey bulamazlar. Ancak bazı propagandacılar ilgili oldukları cıkarlan bilinçli olarak saklamaktadurlar.

\section{YENI BIR TANIM}

Bütün bunlardan sonra, uluslararası toplulukta propaganda amacıyla girişilen veya girişilecek olan edimleri açıklayabilecek yeni bir tanım önerebiliriz. Böyle bir tanım önerirken, çoğunlukça bir propagandacıya yakıştumlacak eylem ve edimlerin hepsini kapsamak, bunun dışında hiçbir şeyi tanımımızın içine almamak bizim için temel ilke olmalıdır. Bu açıdan bakllırsa propagandanın, bir bireyin veya grubun başka bireylerin veya gruplarin tutumlarin belirleyip biçimlendirmek, kontrol altına almak veya değiştirmek için, haberleşme araçlarindan yararlanarak ve bu bireylerin veya gruplarin belirli bir durum veya konumdaki tepkilerinin kendi amaçlarına uygun tepkiler şeklinde olacağhn umarak giriştikleri bilinçli bir faaliyet olarak tanımlanması mümkündür. Propagandacı bu tür bir girişimde bulunan tek bir birey olabileceği gibi, bir grup da olabilir.

Bu tanımdaki "bilinçli girişim" terimi propaganda kavramının en can alici yaninı dile getirmektedir. Bu terim, propaganda olanla propaganda olmayanı biribirinden ayırmaktadır. Bundan önceki sayfalarda herşeyin propaganda olarak kullanılabileceği ve propaganda çerçevesine girmek için hiçbir şeyin özel nitelikler kazandırmlmaya ihtiyacı olmadığını belirtilmiştir. Bu nedenle, açıtıtı ki, herhangi bir edimin propaganda sayilabilmesi için, böyle bir edimin. tutumlar üzerinde kontrol kurarak belirli eylemlere yolaçmayı bilincli olarak hedef edinmis bir kampanyanin içeriği arasinda yeralmiş olması gerekir. Bu bakımdan, herhangi bir sözün, kitabın, afişin, dedikodunun, geçit torreninin, serginin, heykel veya tarihsel abidenin, bilimsel bir bulusun, veya istatistik dökümünün, bunlar doğ- 
ru ya da asilsiz, rasyonel ya da irrasyonel de olsa; ancak tutumlar üzerinde kontrol kurmak ve böylelikle bu tutumlarn değiștirmek isteyen birinin izlediği bilinçli bir eylem siyasetinin gereği olarak yaratılmıs veya oluşturulmus bulunduklart saptanabildikten sonra, bütün bunlarin propaganda araci veya materyali olduklar ispat edilmiş denektir. Herhangi bir toplumdaki veya herhangi bir dönemdeki propagandanın hacmini veya doğasını incelemek isteyen bir araştırmacının da, elealmak istediği her propaganda görünüşlü edim veya eylemin ardında bir propagandacının bulunduğunu ortaya koymakla işe başlaması gerekir. Çoğu defa bunu yapmak kolay olmıyabilir, fakat herhangi bir eylem veya edimin bir grubun tutumlan üzerinde kontrol kurmak için girişilmiş bilinçli bir faaliyetin bir bölümü olduğu ispat edilemedikçe, propaganda niteliğine sahipmiş gibi görünen, fakat propaganda olarak kabulü olanakstz bir eylem veya edim olarak kalacağı bilinmelidir.

Propaganda, ikinci olarak, başka grupların tutumları üzerinde kontrol kurmak veya bunları değiştirmek veya "biçimlendirmek" için yapilan bir girişimdir. Kamu-oyu üzerinde kontrol kurmak için girişilen eylemlerde temel varsayım. belirli durumlar karşısında bireylerin ne gibi tepkilerde bulunacaklarını belirleyen tutumların dis etkilerin etkisinde oldugu; bu etkilerin ise kısmen kontrol altına alınabileceğidir. Propagandacılar bilinçli olarak işte bu dış etkenleri kontrolleri altına almaya çalışılar. Bunu, bazan yeni bir durumla ilgili olarak yeni bir tutum yaratmak, bazan varolan bir tutumu sürdürmek ve bu tür tutumları bozucu güçlere karşı korumak, bazan da varolan tutumlardan bazllarının yerine kendi amaçları için daha uygun yeni yeni tutumların oluşumunu sağlamak için yaparlar.

Üçüncüsü, propaganda tek tek bireylerden çok, gruplan kendisine hedef alır. Fakat propagandacının faaliyetlerinin bu geniş çaplı olma özelliği, propagandanın içsel doğasının değil de, bu konudaki alışkanlığın bir sonucu saylabilir. Başka bir deyişle, tek bir bireyi ikná etmeye uğraşan kişinin çalışması ile böyle bir kişinin bütün bir sosyal sınıfı ikna etmek için çalışması arasında temel bir farkhllk yoktur. Ne var ki, propaganda denilince akla bu sonuncusu gelmektedir. Propagandanın toplumsal bir önemi vardır; "ulusal gençlik", "seçmen oylar", "emekçi sınıfı" veya "ulus"un" kendisi gibi büyük gruplar üzerinde kontrol kurmak girişiminde bulunduğu için de siyasal bilimciler ve sosyologlar için inceleme konusu olmaktadır. Fakat birşeyin propaganda sayılması için yeterli saylabilecek belirli bir miktar, tam bir sayı bulunmuş değildir; böyle birşey yoktur. Propaganda, esas olarak, az sayıdaki bireylerin büyük gruplara 
erişme çabasına dayandığı için "propaganda" olarak adlandımımış ve özel bir ilgi alanı hâlini almıştır. Bu bakımdan en azından bir tek gözlemcinin dikkatini çeken ve toplumda geniş bir alana seslenmeye çalışan herhangi bir propaganda ediminin "propaganda" sayılması geçerli sayslabilir.

Tanimimizda tutumlar üzerinde kontrol kurmaktan sözederken "haberleşme araçlarını kullanarak" deyimi kullanılmıştı. Dördüncü Bölümde aymntı olarak göreceğimiz "haberleşme araçları" terimi insanın insana bir görüş veya düşüncesini bildirmekte yararlanabileceği bütün araçları kapsayan genel bir terim olarak kullanılmıştır. Bir bakıma, Lasswell'in "semboller" derken anlatmak istediği de bu olsa gerektir. Sözlü veya yazılı dil, resme dayanan temsil, müzik, oyunlar, sergiler ve gözle veya kulakla algilanabilen herşey "haberleşme araçlar" kavramının kapsamı içindedir. Haberleşme araçları alanında propagandacının önünde bu denli çok alternatifin bulunuşu, propagandanın kullandığ haberleşme aracina göre belirlenmesini güçleştirmekte ise de, "propagandanın şiddet kullanma veya rüşvet ve menfaat sağlama yoluyla yürütülen iknâ türlerinden ayurt edilebilmesi için, "haberleşme araçlarından yararlanma" şartına propaganda tanımında yervermek gerekli görünmektedir. Propagandacl servet ve zenginlik vaadedebilir, şiddet kullanımı tehdidinde bulunabilir, veya başkalarının sahip olduğu servet ve zenginliği dikkatleri çekebilir, eziyet çekenlerin durumlarını görülgen hâle getirebilir, fakat propagandacı olarak, rüşvet ve yolsuzlukla şiddet kullanımina ortam hazırlayamaz. Propagandacı başkaları kendisinin istediklerini yapsın diye zor kullanamaz; propagandacı başkalarının kendi istediklerini yapması için gerekli koşulları oluşturarak bu amacina ulaşmak ister.

Propagandanın bir başka önemli yanı da, tanımımızda, "belirli bir durumda, etkilenen kimselerin propagandacının istediği tepkilerde bulunmaları amacıyla" sözleriyle belirtilmiştir. Propagandacı, bu tanımda, varolan veya gelecekte meydana çlkacak olan bazı belirli durumları düşünerek, kişilerin kendi istediği eylem ve edimlerde bulunmalarını sağlamak için, düşündüğü bu durumlarda bağıntılı belirli tutumları oluşturmaya çalışan biri olarak değerlendirilmiştir. Propagandacinın gözü şeylerde değil, sonuçlardadır. Propagandacı kendi mesajını dinleyenlerin, sonunda, propagandacınin istediği şeyleri yapacağını umduğu için girişimde bulunur. Propaganda sırasında yayılacak olan materyal ve bunun yayılışında izlenecek biçimin seçimi, propagandacının istediği sonuçlar oluşturmakta taşıdıkları etkinliklere göre olur. Propagandacının hedefi sadece tu- 
tum değișikliği yaratmak değil, sonunda, eylem alanında bir eylem olarak görülecek tutum değişikliği yaratmaktır. Örneğin, iki-partili bir sistemde üçüncü bir siyasal parti kurulduğunda böyle bir partinin propagandasını yürüten kimselerin seçmenleri sadece bu partinin önderlerinin görüşlerinin doğruluğuna değil, fakat seçimde üçüncü bir parti için oy kullanmalarının boşuna oy kullanmak demek olmayacağına da inandırmaları gerekir. Bu durumda propagandacinın başarısı için gösterge, seçmenlerde tutum değişikliğinin olup olmaması değil, üçüncü partiye oy veren seçmenlerin șayısının artmayışı olacaktır.

Tanımda belirtilen propagandacının kişiliğinin ortaya çıkmasından kastedilen, kişisel tanıma veya propagandacı hakkında yapılan öznel bir değerlendirme değildir. Propagandacı belirli amaçlar için başka grupların tutumlarını kontrol altına almak isteyen biridir. Bu amaçların veya kullanılan araç ve yolların moral veya siyasal nitelikleri hakkında yapılabilecek değerlendirmeler konu ile ilgili değildir.

Yukarda yapılan tanımın ışığı altında, propagandacı denen kimseler propaganda kuruluşlan adını taşıyan Ulusal Aydınlanma Bakanlığı, Psikolojik Savaş Kurumu, Ulusal Moral Bakanlığı, Savaş Enformasyon Dairesi gibi yerlerde; ya da siyasal partilerin, devletin, siyasal nitelikte kuruluşların Halkla İlişkiler Birimlerinde çalışan kimselerdir. Belirli bir politikayı destekleyen bütün gazetelerin genel yayın müdürleri ve yayıncılarn; ister tutarlı bir uygulama, isterse tek tek edimleri itibarıyla olsun, kendi resmi kapasiteleri oranında bütün politikacılar; Sendikalar, İsverenler Birliği, Ulusal Kurtuluş Komiteleri veya belirli bir siyasal, ekonomik veya sosyal siyasete taraftar veya karşıt nitelikte fikirler savunan diğer her çeşit kuruluşlarda sözcü olarak çalı̧̧anlar da bu tanimın kapsamına girer. $\mathrm{Bu}$ gruplarnn sözcüleri veya bu tür kişiler konuştuğunda veya bir açıklama yaptığında, amaçlamnın bizim tutumlarımız üzerinde etkide bulunmak olduğunu anlama olanağımız vardır. Eğitim Bakanlığında çalışanlar, bireysel yayıncılar ve sözcüler ise, bilinçli olarak belirli bir ideolojinin yaramna çalıştıkları takdirde propagandacı sayrlabilirler. Aynı şekilde, bir yazar salt sosyalizmi kötülemek için bir kitap yazarsa, sosyalizmi kötülemekten başka bir amaç taşımayan böyle bir kitabın yazarı propagandacıdan başk birşey sayılamaz.

Bu nedenle, propaganda olduğundan kuşkulanılan bir şey karşısında siyasal bilimcinin yapacağı iş, eldeki materyalin bir propa- 
gandacı tarafından bilinçli faaliyetinin sonucu ve ürünü olduğunu ortaya koymaktır. Özellikle mimari üslùbun siyasal sembolizmi gibi ilginç konularda bu alanda delil bulmak bazan güç olsa bile, propaganda niteliğinin saptanabilmesi için bu işin yapılması bir çeşit önkoşul sayılmalıdır. Siyasal bilimci propaganda diye elealdığı §eyin, herşeyden önce, propaganda niyetiyle oluşturulmuş bulunduğunu göstermek zorundadır. Burada işin iyi olan yanı, propagandanın kökeni sorununun gözlemci durumundaki kimsenin ethic değerlendirmelerinden etkilenmeyecek bir olgu sorunu oluşu; herkesin bildiği bir propaganda kuruluşu tarafundan meydana getirilmiş olduğu anlaşılan birşeyin propaagnda olarak tanımlanabilmesidir.

Bütün bunlardan sonra; artık, herhangi bir tanımın standard gerekirliklerine uygun olarak yapılan propaganda tanımımızın özelliklerini belirtebiliriz. Önce, tanımımız bu tanımı yaparken düşündüğümüz görevini yerine getirmiş olmaktadır. Yaptığımız tanım, propagandada propagandacının kişiliğinin tanınması ile kişisel değerlendirmenin veya bu konudaki kişisel bilgilerin aynı olmadiğını vurguladığı, veya en azından, sübjektif değerlendirmelerin fazla önemli olamayacağını işaret ettiği için, konunun bilimsel olarak irdelenmesine yol göstermiş olmaktadır. Tanımımız farklı siyasal kanaatlara sahip çeşitli kimselere, bunlar yanyana geldiklerinde, aynı şeyden söz ettiklerine inanabilme olanağı da vermektedir. İkincisi, tanımımızda bütün kavramlarnn anlamca içerikleri ifade edilmiş bulunmaktadır. Tanımımız olası bütün propaganda örneklerini kapsamakta; ilgisiz olan ne varsa bunlamn hiçbirini kapsamı içine almamaktadır. Üçüncüsü, tanımlamada kullanılan tanımlayıcı karakteristiklerin hepsi de objektif bir inceleme veya yoklama ile saptanabilecek açıklıktadır. "Dürüst", "irrasyonel", "tarafgir" veya "tek-yanlı" gibi bulanık veya hissî kelimelerden elden geldiğince uzak kalınmıştır. Bu sayede de, propagandacının kişiliği sorununun gözlemenebilir bir olgu sorunu niteliği kazanması sağlanabilmiştir. Bunda, moral, siyasal ve ekonomik saiklere bağlanmamış olunmasından yararlanılmış; propagandacı durumunda bulunan biri, böyle birisi kamunun tutumlarn üzerinde etkide bulunma niyetini taşıyorsa, propagandacı olarak kabul edilmiştir. Son olarak, tanımımız propaganda faaliyetinin gözlemlenebilir özelliklerini saptamak için de kullanışlı görünmektedir. Tanımımız Goebbels'in Halkı Aydınlatma ve Propaganda Bakanlığ veya Birinci Dünya Savaşında İngiltere'deki "Crewe House" gibi kuruluşlarn amaçlarmı açıklamakta da yararlı olmaktadır. Tanımımız çoğunlukla herkesin propaganda olarak kabul ettiği herşeyi içermekte; kelimenin genel anlamdaki kullanımını açığa kavuştur- 
makta, fakat bu anlamı değiştirip aslından farklı bir görünüm içine sokmamaktadir.

Olağan yetenekte bir araştırmacı bu tanımı kendisi için bir temel saydiktan sonra, belirli bir toplumdaki propagandanın hacmi ve doğası üzerinde incelemelerine başlayabilir; aynı enformasyondan yararlandırıldıklarında, değişik moral ve siyasal ölçülere sahip başka araştırma.cıların da aynı sonuçlara varacaklarını ümit edebilir. 


\section{PROPAGANDANIN GELISIMII}

\section{Bölüm : 2}

\section{PROPAGANDACI İCINN KITLE}

Modern kitle propagandasının büyük ve önemli bir siyasal güc olarak ortaya çıkışı ondokuzuncu yüzyıl sanayi toplumuyla birlikte oluşan koşulların çok özel bir eşkonumlanmasının sonucu sayılmalıdır. Yirminci yüzyılın diğer etkileriyle de pekişen bu koşullar siyasal işlerimizin icra ediliş biçimlerini etkilemeye devam etmektedir. Propaganda günümüzdeki önemini kazanmadan önce, toplumdaki "muhteris" kimselerin siyasetle ilgilenmeyen çoğunluğun görünüşte gönüllü ittifakını kazanmak zorunda kalmaları gerekiyordu. Bunun olması için ise, siyasal önderlerin, hiç olmazśa şeklen, yönetilenler kitlesinden kendi otoritelerine destek aramak zorunda kalmalan gerekmekteydi. Bunun böyle olmadiğı toplumlada ise, kitlelere önem verilmez, olağanüstü bunalım dönemlerinde kitleler şiddet ve korkuyla susturulurlard. Fakat genel oya olan inancin zamanla yaygmlaşması ve tebanın da yöneticiler kadar idrake sahip olabileceği düşüncesinin gelişmesiyle birlikte yöneticilerin, sadece şartların zorunlu kıldığı günlerde değil, fakat heran için kamu-oyunun desteğini araması gerektiği; bunun, şartlar gerektirdiği için değil, kendi doğasından dolayı iyi birşey olduuğ kabul edilmeye başlamıştır. Politikacılar ise kendilerinde gördükleri yönetme hakkının, normal olarak siyasetle ilgilenmeyen kitlelerden belirli dönemlerde onay olmadıkca bir anlam taşıyamayacağını anlamışlardır. Komuta konumundaki otoritenin halkın onayını alması gereğinin farkına varılması, bir ölçüde, onsekizinci yüzyıldaki Federalist'lerin yazılarının verdiği ilham ile olmuştur. Toplumun iktidar-bilinçli üyeleri halkın desteğini kazanmak için propaganda tekniklerinden yararlana-

- bileceklerini; günün değişen yeni koşulları karşısında ise, halk desteğinin eskiden kullandıkları rüşvet ve menfaat sağlama yollarından veya şiddet kullanımından çok daha etkin olacağını sezinlemişlerdir.

Siyasal hayatta kamu oyunun rol konusundaki tutumları değis meyenler bile, bugün, propaganda yolu ile barışçı ikna yöntemlerinin 
işleyişini öğrenmek zorunda olduklarını görmüşlerdir. Oy verme hakkının yaygınlaşması ve nüfusun bu denli artışı karşısında başka bir yol izlemek [çıkar sağlamak, rüşvet vermek gibi, c.n.], bugün, izlenmesi güç ve çok pahalı görünmektedir. Bir zamanlar satın alınmakta olan seçmenlerin bugün ikna edilerek kazanılması gerekmektedir. Bu bakımdan günümüzde politikacılar için propaganda ile ilgilenmekten daha uygun bir iş olabileceğini söylemek güçtür.

Bugünkü anlamıyla propaganda kelimesinin düşünce ve görüşlerin geniş çerçevelere yaygınlaştırılması işlemini ifade ettiği belirtilmelidir. Sosyologlar ve siyasal bilimcilerin propaganda sorunu ile ilgilenmelerinin nedeni, bazı kimselerin veya bazı küçük gruplamn propaganda kanalıyla bireylerin veya küçük toplulukların değil, fakat ekonomik sinıfların, din topluuklarını, irklarnn, siyasal partilerin veya uluslarnn bütün üyelerinin birden düşünce ve eylemlerini kontrol altına almak amaci gütmeleridir. Bu alanda kullanılan "kitlesel iknâ" kavramı son derece yararlı bir kavram olmakla beraber, anlamca bulanık kalmış, kesinlikten uzak bir kavramdır. Bir şeyin propaganda olup olmadığını seslendiği kitlenin hacmi açısından saptamak için gerekdi olan sınır ne olduğu bulunmuş, bilinen bir şey değildir. Bu konuda söylenebilecek tek şey, birşeyin siyasal bilimcilerin ve sosyologların ilgisini çekecek kadar yoğunluk kazandığı noktadan itibaren üzerinde durulmayı gerektirecek hacme ulaştığı ve propaganda sayılabileceğidir. Propagandanın genellikle büyük ölçüler içinde bir kanaat oluşturma işlemi niteliği taşıması ise, propagandanın siyasal bir önem kazanmasına yolaçmaktadır.

Propagandacı herşeyden önce, çok büyük ölçüler içinde kitleleri ikna çabasında olan birisi ise de, bu duruma bakarak propagandacının herzaman büyük ölçüler içinde ve dolaysız olarak kitlelere seslendiğini sanmamalıyız. Birçok durumlarda propagandacı, örgütlü grupların veya büyük topluluklarm kanaat önderlerini etkileyerek amacına ulaşmasının daha etkin bir yöntem olacağını bilir. Örneğin, bir grubun propagandacısı kitlelere sesini duyurmaya çalışıken, bir başka grubun propagandacısı gazete genel yayın müdürleri ve patronlarına ziyafetler vermeyi, o'nları çeşitli toplantılar düzenleyerek ağırlamayı yeğleyebilir. Savaş propagandasında olduğu kadar. Soğuk Savas döneminin propaganda faaliyetlerinde de yapılan propagandanın büyük kısmı son derece uzmanlaşmış nüfus kesitlerine yükseltilmiş bulunmaktadır. Bunlar için, başlıca, sanayiciler, profesörler vb. örnek verilebilir. Birçok çıkar grupları, özellikleri gereği, sadece çok küçük bir nüfusa seslsnmek; küçük bir toplulukla ilişki kurmak durumundadır. Bunlar, aydınların, zengin- 
lerin veya önemli siyasal kişilerin küçük bir kısmı üzerinde etkide bulunmakla yetinebilmektedirler. Fakat bu tarz propagandaya yönelmeleri de kitlesel propaganda kapsamı içinde yeralmalıdır. Çünkü, bunlarda da amaç, toplumu yöneten az sayıdaki bireyler üzerinde etkide bulunarak, kitleleri etkilemek olmaktadir.

Propaganda ile ilgili sorunlarda kullanlan "okuyucu-dinleyici-seyirci kitlesi" kavram oturmuş ve olgun bir kavram değilse de, propagandanın kökeni sorununun kavranması için anlamlı ve yararì bir kavramdir. Bu kavram, propagandanın bu konuda "grup-yönetimli" bir yaklaşımı haklı kılan özelliğini; propagandacının hedef-kitlesinin biribirinden farkl gruplardan oluşmuş bulunduğunu vurgulamaktadır. Buradaki gruplann önemi, bu grupların salt varoluşlarından değil, varlıklarn aracıllğı ile bu grüplar içindeki bireylere diğer gruplardan ayn olduklarını göstermesinden; onlara "grup-bilinci" kazandırmasından; bu "grup-bilinci" ile bireylerin gruba üye olduklarmı hissetmelerinden ve ortak çlkarları ile ilgili konularda ortak yanitta bulunabilmelerindendir. Bireylerin statülerinin veya sosyal rollerinin "farkında olmalar" propagandanın başar kazanması açısından önemli bir sorundur. Propagandacı dolaysız olarak gruplara seslenirse de, grup üyesi olan bireyler üzerinde etkisini kuramadıği sürece, tam bir başarı kazanamaz. Diğer yandan, grup üyesi bireyler grup üyeliklerinin yeterince bilincinde olmadıkça da propagandacının başarı kazanması kolay olmaz.

Ondokuzuncu yüzyıl Avrupa'sında sınaîleşmenin ardından ortaya çıkan nüfus artışı ve kentlileşme toplumda oluşan yeni sınıfların ve grupların kendi sinıf ve gruplamnın bilincine varması için gereken ortamı hazırlamıştır. Sinaîleşmenin tamamlandığı bütün bu dönem boyunca devamlı olarak köylerden kentlere akın olmuş; kentlerdeki fabrikalar artmış; gitgide daha büyükleri yapılmış; bu fabrikalarda çalışan işçiler yoğun yerleşimli mahallelerde yaşamaya başlamışlar; bütün bunlar insanların o zamana kadar görülmedik ölçülerde kendi sosyal ve ekonomik smiflarının bilincine varmasına neden olmuşlardır. O zamana kadar dokuz-on işçinin bulunduğu bir kasaba veya köy atelyesinde çalışan bir iş̧̧inin, arkadaşlarından çok patronuna kaŗ̧ı bağlılık duygusu beslemesi olanağı varìğını sürdürebilmiştir. Sinaî toplumunun oluşumundan önceki dönemde işçi durumundaki bir kimsenin kendi "sınıfının" sayısal gücünün bilincine varabilmesi; benzer iş dalında çalışanlaria ilişki kurmak için gerekli araç ve yöntemleri bulup öğrenmesi söz konusu olamazd. Fakat iki bin işçinin çalıştığı bir fabrikada işe giren bir işçi kendisi ve kendisine benzeyen kimselerle fabrika yönetici ve 
sahipleri arasındaki başkalaşmayı farketmeye zorunlanmış oluyordu. Bu durumdaki bir kimse kendisinin de ötekiler gibi "işçi" olduğunu görür, öğrenir ve buna inanur; ardından da, "işçi sınıfına" seslenen veya yönelen mesajlara kulak vermeye başlar. Sınaileşen uluslarda yeni toplumsal yapi bireylerin sinff bilínci kazanmalannin önemini vurguladığı için de, sınıf farkhlaşmalarının belirginleşmesini kolaylaştırmıştır. Bu dönemin Jane Austen'den H.G. Wells'e kadar çoğu roman yazarları, doğru bulmuyor olsalar bile, katı toplumsal tabakalaşmanın iyi bir toplum için önkoşul sayıldığı bir toplum hayatını yansıtmışlardır.

Eşitlikçi demokrasi yüksek derecede farklılaşmış bir sosyal sınufsal yapının antitezi olma savı ve ümidiyle ortaya çıkmıştır. Bu açıdan düşünüldüğünde, demokrasinin gruplara yöneltilen propagandaları azaltması gerekirdi denilebilir. Fakat bu böyle olmamıştır. İngiltere ve çoğu Avrupa ülkelerinde ondokuzuncu yüzyılda geleneksel sınıf farklılıkları yeniden canlanmış, hatta daha da güçlenmiştir. Atlantik'in öte yakasında, Birleşik Amerika'da ise daha gelişkin ve progressive bir toplum kurulmuştur. Biribirine özünden ters düşen bu iki gelişmenin ortak bir yanı da olmuştur : bireyin yerine toplumun yeğlenmesi. Bir süre sonra Avrupa toplumlar da Birleşik Amerika'daki gelişme yönüne benzer bir yön tutmuşlar, fakat İniltere'de Viktorya devri sinif farklliklarının zayıflaması, propagandacılar için çok önemli grup düşüncesinin de zayıflamasına yolaçamamıştır. Gerçekten, burada sorunu Tecqueville'in Amerika'daki eşitlik hakkındaki sözleriyle ifade edecek olursak, yeni demokratik toplumlarda, bu toplumlarn niteliklerinin sonucu olarak, birey ancak kamu oyunun siperi altında yaşamasını sürdürebilmektedir.

Eşitlik dönemlerinde insanlarnn biribirine benzemeleri yüzünden insanların biribirine inancı-kalmaz; fakat gene bu benzeşme sayesinde insanlar kamunun yargısının doğruluğuna neredeyse tam bir inanç beslemeye başlarlar; ${ }^{1}$

Kitle toplumunda bireyin geleceği ve kaderi de Tocqueville gibi aristokratik ve bireyci birine, bireyin çoğunluk yargilarına baskı ile uyumlanmasını katlanılmaz bulunduğundan, üzücü ve tatsız görünmüş olabilir. De Tocqueville'in görüşünce, demokraside kitleler cahillik ve hoşgörü yoksunlukları yüzünden ( $k i$, o günkü eğitim standardlarıyla bunlarmn giderilmesi güç görünüyordu) ister istemez bir

1 A. de Tocqueville, Democracy in America (World's Classics Ed., Oxford University Press, 1945), ss. 297-298. 
tiranlığa yolaçacaklardır. Bu tiranlığa karşı yapılabilecek tek sey, demokrasinin yaratacağı bu halk tiranlığının aklın ve adâletin yönetimi altına alınması olacảktı. Çoğunluk 'düşünce ve kanaat özgürlüğünü önleyici öylesine engeller"' ${ }^{2}$ koyabilir ki, bu baskılardan etkilenen bireyler için bu tür engeller de tek kişinin tiranlığında görülenler kadar katlanılmaz olabilir. (*)

Sadece sonuçlarla ilgilenen propagandacı ise, kanaatlarla ilgili alanlarda ortaya çıkan bu herkese benzeme ve herkese uyma eğilimini kendisi için siyasal hayatın en yararlı olgusu olarak kabul etmiştir. Propagandaclar, psikologlar ve sosyologlar grup düşüncesinin "niçin" ve "nasıl" oluştuğu sorununu incelemeye başlamadan çok daha önceleri, grup düşüncesi üzerinde kontrol kurma konusunda pratik denemelerde bulunmuşlardır. Gerçekten, propaganda siyasal hayatta en önemli güçlerden birisi olarak kendini kabul ettirinceye kadar, bunun nasıl ve ne gibi koşullar nedeniyle mümkün olabildiği hakkında hiçbir ciddi araştırma yapılmış değildir. Propagandacıların böylesine başarı kazanmalarının nedenleri konusunda ilk açıklama arayışlarının başında, özellikle, William McDougall, Graham Wallas, Walter Lippmann ve Wilfred Trotter'in çalışmaları gelir. ${ }^{3}$ McDougall ve Wallas insanlarn eylem ve edimlerinde içgüdülerin ve rasyonel-olmayan saiklerin rolü konusunda öncülülk etmişlerdir. Bu iki yazarın teorilerini burada özetlemeye çalışmak yersiz olacaktur. Fakat burada hemen belirtelim ki, herikisinin teorileri

2 Ibid, s. 192.

(") Bu tür "seçkinci" ve "demokrasi-karşıtı" síyasetçilerin açıklamaları ikili özellik taşıyor: (a) Ondokuzuncu ve Yirminci Yüzyılda doruğa çıkan "demokratik" yönetim biçimlerinin ve genel olarak kültür yaşamının "demokratikleşmesinin" ortaya çıkardığı görüntülerden hoşnut olmamalarn; (b) bu hoşnut olmadikları görüntülere demokratik yaşamda etkin hâle gelen "halkın". "avamin". "sıradan insanın", mediocre mob dedikleri "kalabalıkların" neden olduğunu sanmalar.

Gerçekte ise, heriki yönden de, bu açıklamalarının iler-tutar bir tarafı yoktur. Siyasal yönden devri bitmiş bir sınıfın hülyasıdır bunlar. Siyasal tahlilleri çok yüzeyden, çok hissî, ve çocukcadır. Modernleşme süreciyle birlikte yitirmeye başladıkları 19. Y.Y. öncesi durağan ve eşitlik-karşıtı bir toplum yaşamının özlemcisidirler. Olan-biteni anlamaya çalışacakları yerde, kapitalist modernleşme sürecinden en çok etkilenen sıradan insanlari bu sürecin "sahibi" ve "nedeni" olarak görmekte; içlerini boşaltmak için, bu kesimleri "sahipsiz" ve "kolay" bir hedef olarak ortaya dikmektedirler.

3 W. Mc Dougall, An Introduction to Social Psychology (1908); G. Wallas, Human Nature in Politics (1908) ve The Great Society (1814); W. Lippmann, A Preface to Politics (1913, ve Public Opinion (1922); ve W. Trotter, Instincts of the Herd in Peace and War (1916). 
de üzerinde durulmaya değer teorilerdir. Özellikle Wallas'ın, insanın akıldan çok, "hissiyat ve içgüdülerine" göre yaşamasına rağmen, insan faaliyetinin ancak bir kusminin ve ancak bazan irrasyonel nitelik taşıdığı; ayrıca, insanın yaşamında rasyonel davranışların oranının arttırılabileceği şeklindeki düşünceleri ayn bir önem taşımaktadır. Bu görüş, kamu oyunun istenen yönde biçimlendirilmesinde propagandanın sınırlı bir güç taşımasının nedenlerinden birini aydınlatmakta yararlı olmuştur.

Wallas The Great Society adl eseriyle "telkin" kavraminı bu alanda kullanan ilk düşünür olmuş; bu kavramı şöyle açılamıştır : "tek olumsuz yanlanyla, tam bilinçli olmayışlarıyla biribirine benzeyen birçok değişik süreçlerle oluşan edimlerin, inançların veya hiselerin sonucu." $\mathrm{Bu}$ aşamada, kanaat-biçimlendirmenin fiili süreci önemli görülmemiştir. O günler için, bazı fikir ve eylemlerimizin mantığa uygun düşünme sürecinin sonucu olmasına karşlık, bazılarında mantık ve aklın fazla yeri olmadığını belirtmek yeterli sayılmıştır. Bu ikinci kategıriden rasyonel-olmayan öğelerin tümünün de "telkin" kapsamı içince incelenebileceği ileri sürülmüştür.

Aynı terim daha sonra bir başka Ingiliz yazarı olan Wilfred Trotler tarafindan, rasyonel şekilde ve rasyonel-olmayan şekilde biçimlenmiş kanaatlar arasındaki farklılığ tır. İnsanın kanaatlarının çoğu irrasyonel inançlara dayandığı ve bu şekilde oluşmuş buluıan kanaatlar konuları ve içerikleri itibarıyla rasyonel ve geçerliği sınanı ispatlanabilir [verifiable] bilgiden ayırt edilemeyeceği için, kaanat oluşumunun bu iki sürecini ayırt etmek açısından "telkin" teriminin kullanılması yerinde görülmüştür. Telkin, bu kullanım anlamı itibariyla, kanaatın kendisini değil, fakat bu kanaata varışta izlenen yolu ifade etmek için kullanılmış bulunmaktadır. Trotler'in propaganda konusundaki incelemelere katkısı, bilinçli olarak telkin'in kullanılmasının nasıl politik bir silah halini alabildiğini göstermesi olmuştur. Trotler'in bu katkısı, modern propagandanın oluşumunda bir ön-koşul niteliği taşıan grup üyelerinde gruplarına ait olrna bilinçliliği sorunu açısından anlamlı olmuştur.

Propagandacının, telkin yolunu kullanmakla, insandaki en güçlü güdülerden biri olan sürüleşme [gregariousness] güdüsünden kendisine yarar sağlayacağını anlaması bir dönüm noktası olmuştur. İnsanın bu özelliği ise, insanın düşüncelerinin esneklikten uzak; kendisinin de entelletküel tecessüsten yoksun kalmasina sebep olmuş-

4. Gallas, The Great Society (New York: MacMillan, 1914), s. 128. 
tur. Aynı özellikler sayesinde, propagandacının işi çok kolaylaşmakta; bireylerde etrafa uyma eğilimine ters düşen yeni düșüncelere karşı hoşgörüsüzlük yaratmak bu işe yetmektedir. Çoğu insan düşünsel bir tecritlenmeden ve başka insanlarca sevilmez olmaktan fiziksel tecritlenme kadar korkmaktadır. Bu güdünün etkisiyle, insan, diğer bütün sosyal etkilerden çok, "sürünün ne dediğine" bakmakta; bu konuda duyarlık göstermektedir. "Halk için" diye konuşan ve halk tarafindan da kendilerinden biri olarak kabul edilen bir propagandacının kitlelerin düşünce ve edimlerini oluşturma ya da önlemedeki etkinliği artmaktadır. J.S. Mill'in korktuğu "çoğunluğun tiranlığı" düşüncesi, bu bakımdan, Trotler tarafından propaganda konusunda yol gösterici bir ilke olarak kullanılmıştır.

Insanların ussal tutumlarinı etkilemek amacıyla yapilan telkinler bireylerin "olanı biteni bilmek için zamana sahip olduğundan emin olmak endişesine kapıldıklar" anda çok daha etkin olmaktadır. ${ }^{5}$ Bireylerin "emin olmak isteği" grup bilinçliliğinin en yüksek yoğunluğa ulaştığı savaş zamanlarında en şiddetli hàlini almaktadrr. Örneğin, bu durumlardan hangisi olursa olsun bütün uluslar kendi davalarının doğru olduğuna dair kuşkusuz ve tereddütsüz bir inanç beslemeye başlamaktadır. Savaş durumunda bir ulus, birbirinden çok ayrı ve farkl insanları biraraya getiren "sürüleşme güdüsü" için verilebilecek bir diğer örnektir. ${ }^{6}$

İtalya'da Gaetano Mosca'nın çalışmaları da Tretter'le aynı doğrultuda olmuş; fakat ne yazık ki, Mosca'nın eserleri 1939'a kadar İngilizceye aktarılamamıştır. Mosca, topluluk içinde yaşayan, fakat bağımsız-düşünceli kişileri topluluğun birliği için bir tehlike ve tehditmiş kibi göstermenin nasıl beylik bir propaganda taktiği olduğunu açıklamıştır. Sürüye uymayanlar; kendi başlarına düşünebilenler suçlu, hain, sabotajcı ve düşman olarak tanıtılmaktadır!

Bütün toplumlar için başta gelen bir özellik olan "sürü güdüsü" yüzünden, ister aristokratik ister demokratik toplumlarda olsun, bu taktik toplumların hayatı kadar eski bir propaganda taktiğidir. Yeni olan yanı, siyasal önem kazanışının son on yıllarda tamamlanmış bulunmasıdır. Belirli siyasal kararların sanki bunlar "sürüye" aitmis gibi gösterilmesinden beri siyaset adamları için kitlelerin

$5 \mathrm{~W}$. Trotter, Instincts of the Herd in Peace and War (London: Fisher Unwin, 1916). Trotter'in Le Bon'un Kalabalık (Güruh) adlı eserinden yararlandığı açıkca görülüyor.

6 Trotter, op. cit.. ss. 216-19, Bk. keza G. Mosca, Elementi di Scienza Politica (Italy, 1896). Ingilizcesi, The Ruling Class, H. D. Kahn (New York : MacGraw-Hill, 1939). 
kontrol altına alınması bir neden değil, sonuç sorunu görünümü kazanmıştır. Burada "sürü" terimi ile kastedilen, propagandacının dolaysız olarak kişisel ilgi gösterebileceği büyüklükteki bütün gruplardır. Bunlar bir derneğin üyeleri olabileceği gibi, ekonomik bir sinıf, ya da bir devletin tüm nüfusu olabilir. Bir propagandacı bile, başka bir propagandacının gözünde, "sürü" üyelerinden biri olabilir.

Nüfusun artışı, yoğunlaşması ve sosyal tabakalann oluşması; bunların sonucu olarak başkalariyla uyum içinde bulunmanın ònem kazanması, seçmenlik ve oy kullanma hakkunın yaylması gibi yakın dönemin gerçekleri ondokuzuncu yüzyıl siyaset adamlarının kamu oyu üzerinde kontrol kurma sorunları ile ilgilenmelerini zorunlu kılmiştır. Ancak, bu sorunların çözümlenme biçimlerini başka etmenler belirlemiştir. Bunlann ilki, doğrudan doğruya ondokuzun$\mathrm{cu}$ yüzyılın bireyin sorumluluğunu temel alan liberal felsefesinin kendine özgü özelliklerinin sonucu olarak ortaya çıkmıştır.

Liberal felsefenin sonuçlamndan biri de, kitlelere okuma ve düşünme öğretildikten sonra siyasal güç de kazandırılabileceği; kitlelerin rasyonel varlıklar olarak siyasal hayata katılabilecekleri inancının yayılması olmuştur. Böyle bir teoriye inanılması ise, irrasyonel bir kamu oyunun hursh politikacilar tarafından kötüye kullanılabifeceğini düşünmeyi güçleştirmiştir. Bencil fakat eğitim görmüș bireylerin objektif olarak iyi bir yaşam kurabileceklerine dair bu yarı-dogmatik inanç yüzünden, sodece temel eğitimin her bireyde toplumsal veya siyasal hayata düşünsel erginlikle katılabilme yeteneğini ya da isteğini kazandıramıyacağı gerçeği anlaşılamamıştır. De Tocqueville ve J.S. Mill'in uyrlarina ve Bagehot'un ${ }^{7}$ bu konudaki kötümser yazllarına rağmen, okur-yazarlığın ve oy kullanma hakkının yaygınlaştırılmasıyla hemen kendiliğinden büyük yararlar sağlanacağına olan inanç daha sonra da varlığını sürdürmüştür. Okur-yazarlığà erişmiş, ama diğer yönlerden bakıldığında yeterince eğitim görmediği ve siyasal olgunluğa erişmediği kabul edilmek gereken kitlelere dayanan bir kamu oyunun özel amaçlar için kontrol altına alınması olanağı ilk günler farkedilememiştir. Liberal düşünürler insan doğasını yanlış değerlendirdikleri için, bu düşünürlerin yarattıkları kurumlar eski aristokratların ve kralların tiranlığını yıkmakta yararlı olmuş; fakat aynı anda, gücünü silâhtan de-

7 Bk: W. Bagehot, The English Constitution (Ikinci Basım : 1872), aldığ yer: "Hiç kimso suradan bir emekçinin, hiçbir niteliği olmayan ve sadece bir aile reisi olduğu için sayımlarda yeralan birinin entellektüel sorunlarda yargıda bulunabileceğini iddia edemez." s. 15. 
ğil, bu tür "kamu oyundan" alan yeni bir tür tiranlıkların oluşumu için gerekli ortamı da gene bu liberal düşünürlerin yarattıkları kurumlar hazırlamıştır.

Demokratik liberal siyaset teorisi ile endüstriyel bir toplum ortamında oluşmus siyasal kurumlar da propagandacının kolaylikla erişebileceği ve dikkatini çekebileceği bir kitleye kavuşmasında kısmen rol oynamıştır. Doğrudan doğruya yeni toplumun karakterinin sonucu olarak ortaya çıkan başka koşullar ișe, bu eğilimlerin yoğunlaşmasına sebep olmuşlardır. Çoğu insanın meseleleri rasyonel bir şekilde ele alıp değtrlendirmede gösterdiği doğal yeteneksizliği daha da arttıran bir etmen ise, bireylerin siyasete karşı ilgisiz kalmalar, bu konuda gerekli bilgileri elde etmek için girişimde bulunma istekliliğini göstermemeleri olmuştur. Bu etmen, elbette ki, başkalarının kendi başlarına ve kendileri için bulamadıklan "gerçekleri" ve kanaatları, o'nlan sunmak görevini yüklendiklerini ileri süren propagandacının gerçek amacına ulaşmasinı kolaylaştıran öğe durumuna indirgemiştir.

Bu ilgisizlik de, derinine inilirse, ondokuzuncu yüzyılın kültür ortamının bir ürünü sayılabilir. Olağan koşullar altında, gerçekten yaratıcı nitelikteki düşüncenin oluşturulması maddi olanakların yeterliğine, dışa dönük düşünceye karşı olumlu bir psikolojik değerlendirmenin bulunmasina ve bu konuda yeterli zihin yeteneklerine sahip olunmasına bağlıdır. Yoksulluğu, gürültũsü, pisliği ve maddeci felsefesi kendi varlığından ayrilamayan sanayi toplumu bu türlü olanaklara erişmek için gerekli yolu herkese değil, sadece yurttaşların çok küçük bir nitelik kazanmış bulunan endüstriyelleşmiş ekonomik düzeniyle modern toplum bireylerin siyasal konularda kendi başlarına düşünüp yargıda bulunmalamnı, oldukça yüksek düzeyde entellektüel yeteneklere sahip kimseleri de içeren bir çoğunluk için, olanaksız kulmıştır.

İşverenler fabrika veya işyerlerinde çalışan işçi ve büro personelinin sosyal veya siyasal sorunlar üzerinde tartışmalarına izin vermemekte; uzun çalışma saatleri, güç iş şartları, sağlığa aykın ve aşır kalabalık konutlarda yaşama zorunluğu yüzünden çalışan sınff üyeleri evlerinde bile bu konular üzerinde düşünüp tartışma hâl ve olanağı bulamamaktadır. Gelir düzeyi biraz daha iyi olanlar ise etraflarındaki insanlarla tanışıp yakınłk kuramamakta; modern toplumdaki yaygin âdetler komşular arasinda kolaylıkla ilişkiler kurulmasını önlemektedir. Konuşma, düşünme ve tartı̧̧ma olanağına sahip olacak kadar ekonomik bakımdan iyi durumda bulunanlar ise, zaman ve olanaklamn en elverişli oldư̌̆u anda bile, ciddi toplumsal 
meselelerin konuşmalarda konu olarak elealınmasını nezaketsizlik sayan görenekler yüzünden, bu olanaklardan yararlanamamaktadırlar.

Kentlerdeki fabrika ve işyerlerinde çalışan iş̧̧iler ve büro personeli gitgide kendi düşünce ve yargllarından çok, siyaset "uzmanlarının" imàl ettiği "hazır-işi" düşünce ve yargllara dayanmak zorunda kaldıkları için eleştirisiz okuma alışkanlığ yaygınlaşmış, ucuz ve "kitlelere" seslenen gazeteler arttıkça artmıstır. Devlet kurumunun sosyal dokusu ise, çok geniş kitlelere seslenmeyi sağlayan teknik olanaklarla beraber, propagandacının seslendiği kitlelerde kendisini dinlemeye hazır ve istekli bir dinleyici kitlesi bulmasin münkün kllmıştır. ${ }^{8}$

\section{HABERLEŞME ARAÇ VE YOLLARI}

Propagandacının ortaya çıkması için, propagandacının yaptığı işe karşı toplumsal bir talebin bulunması ve kitlelerin propaganda mesajlarını alabilecek yetenekte olması gerekmektedir. Ayrica, propagandacının materyalini kitlelere ulaştıracak araç ve yolların da bulunması gerekmektedir. Ondokuzuncu yüzyılın en büyük başarılan ise bu alanlarda olmuştur. Modern haberleşme ve ulaştırma çağı 1825 yllında İngiltere'de Stockton-Darlington Demiryolunun açılması ile başlamıştır. Bu demiryolu "mesafelerin ve mekânın insan tarafından fethini sembolize eden" demiryolları ağının ilk halkası olmuştur. Büyük miktarlarda ve çeşit çeşit eşyaların ucuz ve daha çabuk bir şekilde taşınabilmesinin ve ogünlere kadar erişilemeyen yeni toprakların açlilp işlenebilmesi buralara yerleşebilmesinin ifâde ettiği salt ekonomik avantajlar birtarafa, demiryolları propagandanun gelişmesinde de önemli siyasal etkilerde bulunmuştur. Daha çok sayıda insan, daha sık ve daha uzun mesafeli yolculuklara çıkabildiği için, insanların kafasındaki ulus anlayışı giderek daha da sağlamlaşmıştır. İngiltere'de yüzyllarca süreyle komşu ilden gelen bir insan Çin'den gelmiş bir yabancı kadar "yabancl" biri olarak görülmeye devam etmiştir. Morlaix veya St. Brienc'da oturan kimselerin kendilerini önce Breton, sonra Fransız saydığı önceki dönemde bu insanlarla, bunların hiç karşılaşmadığı Parisliler arasında hiçbir benzerlik, hiçbir ortak yan olmamıştır. Demiryolları insanların biribirinden tecrit edilmelerine son vermiş; parça parça topluluklar yerine,

8 Bk: Wallas, The Great Society, aynı yönde bir tartışma yapıyor.

9 D. Thomson, England in the Nineteenth Century, (Penguin Books, 1850), s. 42. 
birleşmiş topluluk olan ulusların ortaya çlışında demiryollarının önemli etkileri olmuştur. Bu sürecin sonunda yöresel lehçeler, yerel gelenekler ve kültürler zayıflamıs, fakat ulus olgusu ve ulusçuluk son derece güçlenmiştir.

Kısacası teknoloji devrimin iki "önemli sonucu olmuştur. Önce, ulusal çapta grupları oluşturmuş ve bu tür grupların üyeleri arasında haberleşme ve ulaştırma olanaklarını sağlamıştır. İkincisi, bunların yanısıra, uluslar topluluğu içinde tek birimin ulus topluluğu olmasına yolaçmıştır. Almanya'nun gelişmesini anlatan Heaton da demiryollarının "Almanyạ'yı siyasal ve ekonomik birliğe kavuşturduğunu ve Alman İmparatorluğuna gerçeklik kazandırdığını; Almanya'nın batıya uzanan Kuzey Denizi ve Manş Denizi hattı; doğuya uzanan Rusya; ve güneye uzanan Avusturya, İtalya ve İstanbul hatları ile Avrupa'yla bütünleşmesini sağladığını belirtmektedir. ${ }^{10}$ Demiryollarının ilk gelişmeleriyle birlikte, eskinin yaylı posta arabaları ortadan kalkmış; bunların ne yolları ne de izleri kalmıştır. Daha sonraları bu karayolu araçlarının yerine otomobilin bulunması ve gelişmesi ise, demiryolları ile başlayan hareketin niteliğini değil, hızını değiştirebilmiştir. Birleşik Amerika'da özellikle ucuz, seri üretim işi otomobil yapımına geçiş sayesinde milyonlarca insanın bir ulus olduklarının bilincine varması sağlanabilmiştir. Otomobil olmasaydı bu kolay sağlanamazdı. Birleşik Devletler gibi geniş bir ülkede siyasal, ekonomik ve kültürel farklılıklar olan bölgelerin bulunması, birliğin tersi eğilimlere sebeb olmaktadır. Bu eğilimin etkileri, örneğin, New England'dan Orta Batı'ya kadar yapilacak bir geziyle hemen anlaşılabilmektedir. Fakat bu eğilim, otomobilin yaygm kullanımı ve Amerikalıların değişiklikten hoşlandıkları için her yıl binlerce kilometrelik yolculuk yapmalar sayesinde dengtenebilmektedir. Otomobilin, bugün de Amerikan ulusal birliğinin sağlanmasında başta gelen bir etmen olduğunu söylemek aşırı bir görüş sayılmamalidir.

Görüș vo düşüncelerin hızla ve etkin bir şekilde yayılmasını sağlayan bir başka etmen de ucuz ve ulusal çapta posta servislerinin kuruiması olmuştur. Posta servisleri yepyeni bir komünikasyon dalı olarak, özellikle, okuryazarlığın yaygmnlaşmasındàn sonra gitgide daha büyük bir önem kazanmıştır. Kısa zamanda bütün ülkelerde kurulan posta servisleri çok kısa süreler içinde ve çok geniş ölçülerde etkide bulunmuş; propagandacıların çok ucuza ve çok çabuk bir şekilde en uzak yerdeki insanlara erişebilmelerini sağlamışlardır.

16 H. Heaton, Economic History of Europe (New York: Harper and Bros., 1836), s. 553. 
Modern komünikasyon gelişmeleri incelenirken özellikle basın büyük bir önemle incelenmelidir. Bunun sebebi, basının propagandada kullanlan bütün iletişim araçları içinde en gelişkininin ve en yaygın şekilde kullanılan olmasıdır. Basının bu önemi, ancak şimdilerde radyo ve televizyon karşısında gölgelenmeye başlamıştır. Bir zamanlar sádece entellektüel bir azınlık için önem taşıyan basın, bir seri teknik yenilikler ve ondokuzuncu yüzyılda çıarılan demokratik yasalar sayesinde, en önemli kitle haberleşme aracı durumuna yükselmiştir.

Modern basının gelişmesini aynntıları ile anlatmak burada bizim işimiz değildir. Oldukça uzun bir tarihçesi olan basının gelişmesi pekçok yazarca ayrıntılarıyla işlenmiştir. ${ }^{11}$ Baskı tekniklerinde gerçekleştirilen yenlikler sayesinde gazete tirajları milyanları bulmuştur.. Aslında bu yenlikler bile, yeni-eğitim görmüş kitlelerin gazeteye yönelik taleplerinin bir ürünü olarak gerçekleştirilmiştir. Ne var $\mathrm{ki}$, artık çok ucuza basılabilen ve satılabilen gazetelerin halk tarafından bu denli aranır kılınması için, halkın okumayı istediği şeylerin ne olduğunu anlamak ve yayın politikasın ona göre belirlemek gerekmiştir. Basın dünyasının bazı "devleti" bu gerçeği ilk görenler arasından çıkmıştır. İngiltere ve Amerika'daki modern basın, büyük ölçüde, artan okur-yazarlığın nasıl büyük bir okuyucu kitlesi yaratacağını gören ve gazetelerini mümkün olduğu kadar en geniş ölçüde kalabalıklara seslenebilen bir gazete şekline sokabilen az sayıda bazı kişilerin çalışmalarının eseri olmuştur. Amerika'da Joseph Pulitzer ve William Randolph Hearst; İngiltere'de Lord Northcliffe'ler ve Beaverbrook gibi kişiler halka seslenebilmekte etkin ve ucuz yollar arayanlarnn izlediği örnek yerine geçmişlerdir.

Varsayım gereği demokrasinin temel özelliği sayılan görüş ve düşünce alı̧̧-verişi özgürlüğünü etkileyen en önemli modern gelişme ise, gazete tirajlarındaki artış olmuştur. Tiraj artışının yanısıra gazete sayılarındaki azalıs ve gazetelerin gitgide az sayıdaki kimselerin elinde toplanması da belirtilmelidir. Nitekim, Birleşik Amerika'da 1920'de 27 milyon olan tüm gazetelerin tirajları toplamı 1957 de 58 milyona yaklaşmıştır. Aynı dönemde günlük gazetelerin 1915'de sayısı 2,502 iken, 1957 'de $1,755^{\prime}$ e inmiştir. ${ }^{12}$

Gazetelerin kitlelere seslenen yüksek tirajlı yayıncılı̆ga başlamaları sonunda oluşan okuma alışkanlığını tatmin edebilmek için basılı yayınlann tür ve içeriklerinde yeni çeşitlenmelere gitmek ge-

11 Bkz özellikle, F. L. Motte, American Journalism (Now York, 1941) ve S. Morison,

The English Newspapers (Cambridge, 1832).

12 UNESCO, Basic Facts and Figures 1859. 
rekmiştir. Son elli yıl içinde her çeşit basılı yayınlarda artış olmuştur. Bu, bugün de devam etmektedir. Kitaplar, dergiler, risâleler, çeşitli bilgiler veren özel konulu gazete ve dergiler gibi herbiri propagandada haberleşme aracı olarak kullanılabilen yayın türlerinde artma olmuştur.

Tıpkı uzaklığın mekanikteki gelişmeler aracllı̆ı ile fethedilmesi gibi, fikir ve düşüncenin yayılmasında bir başka engel olan zaman $\mathrm{da}$, önce telgraf ve telefon, sonra da radyo ve televizyon sayesinde dize getirilmiştir. Bunlardan radyo ve televizyon, bugün en önemli kitle haberleşme aracı olmuşlarsa da, bunlar bugünkü durumlarına gelinceye kadar çok uzun zaman geçmiş; telsizle haberleşmenin esasları yüzylın ilk on yılinda başarıyla ortaya konulduğu halde, kamuya seslenen ilk radyo yayınları ancak $1920^{\prime}$ lerde başlayabilmiştir. Fakat bunun ardından gelen gelişmeler çok hızlı olmuş, radyo ve daha sonraları televizyon günümüzün sinaî toplumlarında insanın günlük yaşantısında vazgeçilmez bir yer kazanmıştır. Batı Avrupa'da ve Birleşik Amerika'da istedikten sonra radyo ve televizyondan yararlanamayacak kimseler herhalde pek az kalmıştır. Yoksulluk bu konuda bir sebeb olmaktan çıkmış; dinsel veya estetik nedenlerle, veyahut da toplumun istediği biçimde yoğurulmaktan çekinenlerin kendi anlayışlan gibi nedenlerle, radyo veya televizyon almayanlar dışında bu araçlara sahip olmayanlar azalmıştır.

Haberleşme sürecinin hızının posta atlarının gücüne bağlı olduğu eski günlerde eski zaman imparatorlukları uzak yerlerdeki beldeleri üzerinde çok sinırlı bir kontrol kurabiliyorlardı. Sömürgeden anavatana bilgi gelmesi ve anavatandan sömürgelere emirnameler gönderilmesi için günlerce, aylarca beklemek gereken eski zamanlarda, yerel komutanların geniş yetkiler kazanmalarını ve bunun bölücü etkilerde bulunmasını önlemek kolay olmuyordu. Günümüzde ise, önce demiryollariyla şimdi de yayın ve haberleşmeyle hem zaman hem de mekân fethedilmiş bulunmaktadır. Resmi raporlar, emirler, enformasyon metinleri siyasal iktidarın etkisi altındaki en uzak köşelere kadar aynı anda gönderilebilmektedir. İlk kez haberleşme ihtiyacına, ve aynı anda da, bu ihtiyaca uygun haberleşme araçlarına sahip bulunmaktadırlar. Aynı şekilde, bugünün propagandacıları da geçmiş dönemlerin despotları gibi geniş bir potansiyel nüfuza sahip olmus bulunmaktadırlar.

\section{REKLAMCILIĞIN ETKISİ}

Buhar makinasının icadı ile insanların inanılmaz büyüklüklerde enerji elde etmesi sonunda dünya pazarlarına tüketim malları akımı 
hızlanmıştır. Ondokuzuncu yüzyil boyunca insanlar hammaddelerden mamül maddeler elde etmekte kullanılacak yeni yol ve yöntemler bulmakla uğraşmışlardır. Metaller, kumlar, kömürler, yünler, pamuklar, killer sınaileşmiş bölgelere akmış; buralardan makina, kapkacak, banyo küveti, gemi, fabrika, demiryolu rayı veya pencere camı olarak geri dönmeye başlamıştır. Fabrikalar, kentler, sokaklar, evier ve insanlar kullansın diye yapilan bir sürü şey öyle tuhaf, öyle beklenmedik nitelikler almıştır ki, sonunda, anlamsız bir bollukla, hatta israfla karşı karşıya kalınmıştır. Üretimin talebi bile aştığı durumlarda ise - ki bu sık sık olmaya başlamıştır-- üretim fazlasını massedecek yeni taleplerin oluşturulması yoluna başvurulmaya başlanmıştır. Toplumdaki ekonomik felsefe tarafından güçlendirilen acımasız rekäbet ortamında, imalât sanayiinde varlığını korumak isteyen girişimciler için önlerinde tek yol kalıyordu : rakiplerini ortadan kaldırmak ve çökertmek. Sanayiciler ve perakende satışla uğraşan ticaret erbabı, günden güne yeni bir sorunla karşı karşıya olduklarının bilincine varıyorlardı : gitgide daha kolay imâl edilen mamülleri satabilmek için, ileri derecede uzmanlık isteyen ve gittikçe güç bir iş hâlini alan satışı yükseltmek. Düşünce ve kanaatların satışını hızlandırmaktan sonra, ticarî reklâmcıllı, mamül satma sanatı da rekabetçi sanayi toplumunun temel özelliklerinden biri hâlini almıştır. ${ }^{13}$

Reklamcılık ve tanıtma çalışmaları zamanla daha büyük önem taşimaya başlayınca, reklâm ve tanıtma teknikleri ve yöntemleri üzerinde daha ciddi inceleme ve araştırmalar yapılmaya başlamıştır. Reklamcılar rasyonel-olmayan telkinin, yeniliklerin çekici oluşunun, tekrarın gücünün ve basitliğin öneminin farkına varmışlardır. İhtiyaçlar reklamcıları bir görüş veya mesajı görülmesi, anlaşılması, hatırlanması kolay ve kendisine uygun edimlere yolaçabilecek şekilde sunabilecek en etkin yöntemleri bulmaya mecbur etmiştir. Günümüzde, konu ile ilgili yazarlardan birçoğu propagandanın gelişmesi ile paralel bir gelişme olan reklâmcılığın gelişmesi arasında bağıntılar olduğu görüşündedirler. Propagandacıların birçok şeyleri ticarî reklamcillkla uğraşanlardan öğrendikleri doğrudur. Gerçekten de modern propaganda teknikleri konusunda yapılan ilk çalışmalarda ticarì olanaklardaki tecrübelerden yararlanılmıştır. ${ }^{14}$ Satacak

13 Ayrıntıl bir reklâmcıllk tarihi burada gereksiz. H. Simpson'un A History of Advertising from the Earliest Times veya G. B. Hotchkiss'in An Outline of Advertising adl eserleri yeterlidir.

14 Bk: örneğin, D. Dcott, "The Psychology of Advertising," Atlantic Monthly, XCIn (1904), ss, $29-36$. 
mamülü olanlar reklâmcılığın her tür ve biçimini de geliştiren ilk kimseler olmuşlar; duvar afişlerini ve markaları Orta Çağ lonca geleneklerinden almışlar; okuma-yazma bilmeyenlerin de anlayabilmesi için berberlerin kırmızı-beyaz şeritli silindirlerine, eczanelerin zehir ve yllan resimlerine bakarak çeşitli simgeler yaratmışlar; bültenler, haber broşürleri ve her çeşit basılı haberleşme aracından yararlanarak mallarını daha çok satmaya çalışmışlardır. Ticari reklämcılığın bu araç ve yöntemleri bulup sınaması, bu araç ve yöntemlerin belirli görüş ve düşünceleri yaymak için geniş çapta kullanılmaya başlamasından çok daha önce olmuştur.

Modern dünyada en eski propaganda biçimi reklâmcılıktır. Reklâmcllık basının gelişmesi ve ticaretin genişlemesinin sonucunda ilerlemiş; propagandaclların, bugün, özellikle başta siyaset olmak üzere, başka alanlarda kullandıkları yöntemlerin çoğu, ticari reklâmcilık alanından aktarılmıştır. ${ }^{15}$

Açık olan bu durumun henüz yeterince anlaşılmayan bir yanı daha vardır. İleri derecede rekàbetçi bir toplumda, mesajını etkin kılmak isteyen reklâmclar, en dikkat çekici uygulamaları benimsemek zorunda kalmışlardır. Zamanla, reklâmcılık tekniklerinin pratikteki uygulamaları ile iş yöntemlerinde yetiştirme programlarının sağladığı bilgilerden birlikte yararlanma yoluna gidilmiştir. Okullarda ise, satı̧ yöntemleri konusunda öğrenci yetiștirilirken öğretmenler bilgilerini en etkin şekilde aktarabilmek için, daha çok, tanınmış, başarılı ve en orijinal reklâmları örnek vermek yolunu tutmuşlardır. Bu öğretmenlerin irrasyonel, çarpııc ve gözalıcı reklâmları önemseme. ve örnek verme eğilimleri yüzünden, belki de istemeksizin, reklâmların sloganlardan, yarı-gerçeklerden mübalağalardan ve telkinlerden başka birşey olmadığı inancı yayılmıştır.

Gerçekten, bu tekniklerin reklâmcılıkta geniş bir kullanım alanı bulduğu doğrudur. Fakat birşeyin reklâm olması için ille de bu öğelere dayənması gerekmez. Bir başka deyişle, reklâm sadece bunlardan oluşmaz. "Esas itibarıyla, insanları bir malı satın almaya kandırma süreci olan reklâmcllık, çoğu kez, irrasyonel, kaba ve avami bir görünüm taşısa da, reklâmcllı̆ın irrasyonel, kaba ve yollardan insanları bir mal satın almaya kandırma sürec்i olduğu söylenemez. Reklâmcilığın veya propagandanın sadece kötü olan yanı ile değerlendirilmesi yüzünden birçok insanın yanlış yargılara varması, demokratik bir toplumda propagandanın ne gibi bir yeri

15 R. S. Lambert, Propaganda (London: Nelson, 1938), s. 32. 
olabileceği sorununu aydınlığa çlkarmakta onemli zorluklar yaratmıştır. Her ne kadar propaganda ile reklâmcllğın gelişmeleri ve bunların kullandıkları teknikler birbirleriyle ilintili ise de, bu ikisinin biribirinden tamamen ayrı iki olgu olduğu da yaygın bir görüştür. Örneğin, William Albig, önce Public Opinion'da (1939) ve daha sonra Modern Public Opinion'da (1956) propaganda da kaynağın sakl tutulmasının daima temel ilke olduğunu savunmuștur. Propaganda, özündeki nitelikler yüzünden, gizli, alttan alta yapılması gereken, kimin tarafından yapıldığı anlaşılır anlaşılmaz, basit bir reklâma dönüşebilecek bir edim sayılmıştır.

Reklâmcılık, reklàmda kaynak açıklandiğı ve reklâmı yapanın niyeti kolaylıkla anlaşılıp çıarılabileceği için propagandadan farklıdır (kaynaklar, bilimsel olduğu ileri sürülen bir araştırma kurumunun sözlerine dayanarak reklâm yapan bir besin maddeleri imâlatçısı firma örneğinde olduğu gibi, saklandiğında ticarî propaganda söz konusudur.) ${ }^{16}$

Fakat bu açıklamanın doğru bulunması zordur. Daha önce belirttiğimiz gibi, örtülü propaganda kavramı ortaya birçok güçlükler ve tutarsızlıklar çıkarmaktadır. Bu konuda propaganda ile reklâm arasında kuşku götürmez benzerlikler bulunduğunu; ikisinin, esasta, aynı şeyler olduğunu, herikisinin -şeyler veya düşünce ve fikirler hakkında insanların belirli bir yönde karar almalarını sağlamak için girişilen süreçler olduğunu kabul etmek daha yerinde görünmektedir. Bu bakımdan "reklàmcıllk" ve "propaganda" çoğu idefa, biri diğerini de ifade edebilen, anlamca ayn içeriklere sahip, fakat aynı olgunun biri ticarì diğeri siyasî iki ayrı görünümü ifade etmek için kullanılan iki kavram sayılabilir. Bu görüş, bir süre önce H.C. Brown tarafindan da savunulmuştur. Bu konudaki tezinde Brown propaganda ile reklämın, her ne kadar reklâm belirli kimselerin yararına mal sattırmayı amaç edinmekte ise de, ayn şeyler saylabileceğini; propagandanın da görünüşte toplum yararınaymış gibi olsa bile, aslında, belirli kimselerin çıkarları için girişilmiş bir fikir ve görüş satışı işinden başka birşey olmadığını ileri sürmüştür. ${ }^{17}$

Propaganda ve reklàm olgularının bu türlü ele alınması insanın, reklâmın propagandaya oranla daha yüksek ahlâki değer taşıdığını söylemek için katlanılması gereken mantık problemlerinden de kurtulmasını sağlamaktadır. Diğter yandan, ticarî reklamlarda da

16 W. Albig. Modern Public Opinion (New York: McGraw-Hill, 1958); 8. 285.

17 H. C. "Advertising and Propaganda," International Journal of Ethics, XI (1828), ss. $39-40$. 
büyük ölçüde siyasal içerik bulunabilmesinden ötürü karşılaşılan sınıflandırma güçlükleri de ortadan kaldırılabilmiş olmaktadır. Bu son nokta özellikle ilginç ve önemli bir noktadır. Gerçekten, büyük firmaların pekçoğu kendi prestij ve adlarının "kamu yaranna" açılan kampanyalarda kuilanılmasını uygun gördüklerinden, bugün neyin siyaset neyin ticaretle ilgili olduğunu birbirinden ayst etmek güçtür. Bu tür reklâmlar için örnek verilmesi gerekirse, 6 Haziran 1953'te Picture Post gazetesinin İngiltere Hükümdarının Taç Giyme Töreni dolayısıyla çıkardığı özel sayıda yayınlanan bir reklâm gösterilebilir.

Sizlere; Barıs ve Ticaret davamızda doğal müttefikimiz, savaşda yoldaşımız, kanca yakınımız ve kuzenimiz Britanya Halkuna, biz Birleşik Amerika'da THE NATIONAL CASH COMPANY'nin kadın ve erkek personeli, sevinçle karşılamağa hazırladığınız bu MUTLU GÜNÜMÜZDE en derin ve en gerçek komşuluk duygularıyla dostluk elimizi uzattığımızı; ve Uluslarımızın geleceğinde ve kaderlerinde bizleri aramızdaki denizden başka hiçbir şeyin ayıramayacağına herzaman olduğu gibi bugün de tam bir inanç beslediğimizi ifade etmek isteriz.

TANRI KRALİÇE II. ELIZABETH'I KORUSUN.

(İmza) S. G. ALLYRING - Başikan

Ticaret, Maliye, Sanayi ve Kamu Yönetiminde Kullanılan Bütün Dünyaca Ünlü Hesap Makinalar, Mukayyit Kasalar ve Para Kayıt Makinaları Imalat İsleri Firması.

$\mathrm{Bu}$ metnin İngiliz-Amerikan ittifakı yararna propaganda yaptığı açıktır. Ama bunun yanısıra, National Cash Rejister Company'nin de bundan yararlanacağı açıktır. Tanıtma çalışmalarının bu iki görünümünü birbirinden ayıracak ve aralarında bir sınır çizecek nitelikte tanım yapabilmek, görülüyor ki, olanaksız denecek kadar güçtür. (*)

(*) Gerçekten bu doğru görünüyor. Nitekim, Amerikan özel sektörünün reklàm harcamaları üzerine yapılan bazı yeni araştırmalar bu "güçlügü" aşabilmek için, yeni bir ölçüt (kriter) kullanmaya başlamıs bulunuyorlar. Bu yeni ölçũte göre, bir firma, yaptı备 reklámlarla kendi ürünlerinin satışını arttırmayı amaçlyyorsa, bu durumda, yapilan reklém bir "reklám" sayılmakta; eğer, Amerikan Demiryollari Birligi, Kimya Endüstrisi Birligi, ya da, bu birliklerdeki büyülc corporate firmalar topluluğu biçimindeki tek tek kuruluşlar yaptıklan reklámlarda demiryolunun karayolu taṣımacilığına göre sahip olduợu/olabi- 


\section{PROPAGANDANIN GITTIKÇE GÖRÜLÜR HALE GELMESI}

Liberal felsefenin, büyüyen sanayi kentlerinin ve nüfustaki hızlı artışın birlikte etkileriyle ortaya çıkan sosyal, ekonomik ve siyasal güçler nedeniyle bugün prcpaganda dediğimiz olgu ile karşılaşmış bulunuyoruz. Ne var ki, propagandacıların bulup uyguladıkları bazl yöntemlerin yepyeni şeyler olması ve "şamatácl" görünümleri yüzünden, birçokları, propagandanın ne olduğu ile, bu "şamatacı" uygulamaların birbirinden ayrı şeyler olduğunu gözden kaçırır olmuştur. Propagandayı propagandanın bu belirli ve seyrek sayılması gereken özel uygulama tarzlarından ayıramama yetersizliği, asıl önemli sorun olan kamuoyu kontrol sürecinin anlaşılması ve aydınlatılması konusunda girişilen çalışmalar üzerinde ciddi ve sakıncalı etkilerde bulunmuştur. Bu sorun, özellikle halk arasında konuya karşı büyük bir ilginin uyanmasına neden olan Birinci Dünya Savaşından sonra önem kazanmıştır.

$\mathrm{Bu}$ konuda üzerinde durulması gereken ilk sorun, siyasal bilimcilerin sosyal hayattaki bu yeni faktörün önemini nasıl farketmiş olduklarıdır. Propagandanın varlığı nedeniyle demokrasinin temelindeki varsayımların yeniden düşünülmesini sezinleyen ilk yazar B. Jerrold olmuştur. ${ }^{18}$ Jerrold $1883^{\prime}$ de, oy lkullanma hakkının genişlemesi nedeniyle kamuoyunun "bakanlarn yöneticiliklerini devam ettirebilmek için dayandıkları bir güç" haline gelmesi yüzünden "kamu oyu imalinin" de çok daha derinlemesine incelenmesi gerektiğini yazmıştır. Kamuoyu imalinin, Jerrold'a göre. "uzun süre çocukluk döneminden kurtulamayan," fakat artık yeni bir görünüm ve önem kazanmış bulunan bir san'at sayılması gerekmektedir. "Kamu oyu imal edenler" ve bunların gittikçe güçlenmeleri sözlerinden de anlaşılacağı gibi, Jerrold, tanıtma ve propaganda çalışmalarının gelişen yeni teknikleriyle birlikte liberal demokrasi anlayışı için ciddi bir tehlike teşkil ettiğini görebilmiştir. Jerrold'a göre, pro-

leceği üstünlükleri, ya da petro-kimya ürünlerinin üstünlüklerini değil de, Amerikan ekonomisinin verimliliğinde büyük firmaların "olumlu" rollerini vurgulamayı amaçhyorsa, bu durumda reklåmın amacı belirli bir "malı" satmak olmaktan çıkıp, ortadaki "toplumsal sistemi" haklılaştırmak (anti-tröst yasalarımn, Sol'un, demokrat kesimlerin tekelci kapitalizme yönelttikleri eleştirileri etkisiz kllmak) ve toplumsal formasyonu politik ve kültürel düzeylerde yeniden-üretmek olmaya başladığı için, yapllan bu tür "reklâmlar" bildiğimiz anlamda "reklâm" değil, bir belirli ideolojinin satışını yapmak olduğu için, yapılan iş, reklâm sayılmaması gereken bir iş olmaktadır.

18 B. Jerrold, "On the Manufacture of Public Opinion," Nineteenth Century, XII (1883), ss. $1080-82$. 
paganda sayesinde, bazı kimseler görünüşte hiç değişmemiş gibi tutarak "temsilì sistemi temelinden zayıflatmak ve geçersiz kılmakta" sonsuz bir güç elde etme olanağına erişmişlerdi.

Ondokuzuncu yüzyılın son yirmi yillık döneminde siyasal bilimciler ve düşünürler yalnızca oy verme hakkının genişletilmesi ve genel oy ile insanllığın sorunlarının çözümlenmeyeceğini farketmeye başlamışlardır. Bundan birkaç yll öncesinde ise, de Tocqueville ve J. S. Mill "çoğunluğun tiranlığından" söz ederek uyamlarda bulunmuşlardı. Bu kere ise, az sayıdaki bazı kimselerin kendi düşüncelerini ve inançlarmı çoğunluğa empoze etmek, sonra da çoğunluğun ağurlık ve gücünü kullanarak kendisinden değişik yönde düşünenleri susturmanın yollarnı buldukları görülüyor. Varılan, gene az sayıdaki birkaç kişinin tiranlığı oluyor. Fakat, bu kere, çoğunluğun iradesine dayanıyormuş gibi görünme olanağı kazanılmıştır. Bu düşünceleri, 1888'de bu konular da yazan S. Kydd'in satırlarında da görmekteyiz :

İktidar genel oyla seçilen bir meclisin elinde toplandiğında, siyasal spekülasyonlar ve içten pazarlıklı söylevciler geçmişteki despotlardan, krallardan ve hanedanlardan bile daha büyük etkinlik kazanabilirier.19

Yüzyılımızın başında ise temsilî hükümet mekanizmasının liberal yaratıcılarının umdukları gibi düzenli işlemediği gözle görülür bir hal almıştır. Demokrasinin teorisi ile uygulaması arasındaki boşluk gitgide gözle görülür bir hal aldıkça, demokratik tezin bütünüyle reddine kadar uzanan geniş bir kırgınlık ve umutsuzluk ortamı belirmiştir. Ostrogorski, Michels ve diğer düşünürleri demokratik liberal düzenin çökeceği şeklinde kehânetlerde bulunmaya iten de işte bu ortam olmuştur. Aynı şekilde Graham Wallas da Human Nature in Politics adlı eserini bu dönemde yazmıştır. Wallas. eserinde bütün bir Avrupa'da demokratik teorinin gündelik hayatta görülen uygulanışının büyük bir hoşnutsuzluğa sebep olduğunu belirtmiştir. Özgürlük, eşitlik, akıl yeteneği ve halk yönetimi gibi kavramların yerine -bu gibi kavramlar bir kenara atılmışlardı- yeni düşünce akımlar yönetim sorununa çok daha "gerçekci" bir yaklaşımla eğilmek; bu konudaki değerlendirmelerde, insan davranışlarından" gözlemlerle eldè edilecek verilere dayanmak gerektiğini savunmaya başlamışlard. Ne var ki, "gözlemlerle elde edilen veriler" çoğu defa, önceki dönemin inanıșlarının düpedüz, ters-yüz edilmiş aynısı olmaktan ileri gidebilmiş de değildi.

$19 \mathrm{~S}$. Kydd, A Sketch on the Growth of Public Opinion (London, 1888), 8. 84. 
Wallas bu tür "gerçekci" yaklaşımların da, halen toplumda yaygin olduğu görülen ondokuzuncu yüzyıl entelektüel dogmatizmi kadar tehlikeli ve gerçek-dışı olabileceğini kavramış bir yazardı. Kendisi iyi bir gerçekci olduğu için, demokrasiye temel teşkil eden bazı belirli varsayımların güçsüzlüğünü görmüş; fakat, bunlara dayanarak anti-demokratik yargılara varanlarn düşüncelerine katılmaya da yanaşmamıştır. Demokrasiye olan inancını yitirmeyen Wallas demokrasiyi daha sağlam temellere oturtmaya çalışmıştır. Bunun için de, önce, geleneksel demokratik anlayışın boş inançlarını açıklamış, sonra da bu boş inançların yarattığı güçlükleri gidermek için çareler önermiştir. Demokratik teorinin kurucular insan onuruna yaraşan ve insanın gelişmesine daha yatkın bir siyasal düzen bulduklarına inanmakta haklı ve içdenlikliydiler. Fakat, siyasal hayatta insan aklının oynayacağı role eleştirisiz bir tutumla aşırı önem ve ağırlık verdikleri için, kendi kurdukları mekanizma; özellikle temsilcilerin seçilmesiyle ilgili mekanizma, kendi ideallerinin gerçekleştirilmesinde hiç de etkin olamamıştır. Bugünkü parlamenter kurumların yaratıcıları, diyordu Wallas, tamamen entellektüel, açıkcạ yanlış ve gerçeklik-dışı bir insan doğası anlayışından yola çıkmışlardır : ${ }^{20}$ "Temel varsayımlam insanların, kendi yararlamna olacak sekilde, usa vurmanın sonucu olan kanaatlara göre hareket edecekleridir." (s. 98) Eğer demokrasinin daha sağlam temellere dayanması isteniyorsa, bu varsayımın terkedilmesi gerekmektedir. "Siyasal düşüncelerini insan doğasının işleyişinin incelenmesiyle elde edilecek verilere dayandıracak olan kimseler, işe kendi kafalarındaki insanoğlunun entellektüel yanına aşır önem verme eğilimini bastırarak başlamalıdır." (s. 21)

İnsanın sadece akıl ile değil, fakat çoğu defa "duyguları ve güdüleri" ile hareket ettiğine dair yargılarına dayanan Wallas, bir adım daha ilerleyerek, bu tür "duygu ve güdülerin" belki de güdümleyici tarafindan istenen yönde eylem ve edimlerin oluşturulması için bilinçli ve kasitlı olarak yaratılabileceklerini ileri sürmüştü. Profesyonel politikacilamn oy-toplama tekniklerinin başarılı bir temsili de-

20 Human Nature in Polltics'de. Alttaki iki paragraftaki atıflar birinci basımdan (1908).

(*) Bunlar da, reel-toplumun karşısında seçkinci bir tavirla yapılan plebce betimIemeler olmaktan ileri gitmiyor. "İnsan dogasında" böyle güdülerin bulunduguunu savunanlar, "toplumun yozlaşması" önlenmek isteniyorsa, her türlü "yozlaşmadan münezzeh" kendileri gibi "aydınlara" kulak verilmesini isteyen; sorunun bundan "ötesini" düşünmeyo yönelmeyen sinik (kinik) aydinlarla aynı görüşü sovunuyorlar, Bu tür moralistik açılama oluyor yapabildikleri. 
mokrasinin işleyişi için ciddi bir tehlike teşkil ettiğini görebilen ilk yazar Wallas değildir. Bununla beraber, belirli bir kurumsal çerçevede insan doğasını en iyi yansıtan şeyin modern oylama pratikleri olduğunu ilk gören Wallas olmuştur. Oy hakkı genişledikten ve sonuç olarak otoritenin kamuoyunu kendisine temel alması zorunlu kulunduktan sonra, siyasal hayat kamuoyu üzerinde kontrol kurma işinde profesyonelleşmiş kişilerin daha bir dikkatle eğildikleri başlica konulan olmuştur. Tanıtma ve propaganda çalışmalarında yeni yöntemlere ihtiyaç duyulurken, bir yandan da haberleşme alanında devrim niteliğinde teknik gelişmeler sağlanmıştır. Aynı dönemde bu yeniliklere sosyal psikoloji alanındaki yeni buluşlar da katılınca insanoğlu "kitlelerin duygu ve düşüncelerinin profesyonel ve acımasız politikacılar tarafından güdümlenebileceği" (s. 201) korkusuna kapilmıştır.

Siyasetle ilgili konular anlamak ve açlklamakta psikolojinin taşıdığı önem Freud'dan zamanımıza kadar birçok yazar tarafından işlenmiştir. Fakat bu bölümde ele aldığımız dönem içinde, propaganda sorunu başta olmak üzere, bu konuda en önemli katklarda bulunan yazar, belki de, Walter Lippmann olmuştur. 1913 yılında yaymlanan A Preface to Politics ve 1922'de yaymlanan Public Opinion adlı eserlerinde psikologlann teknik yöntemlerinin ve bulgulamnın politika bilimine ve politik hayata uygulanması sorunu üzerinde durmuştur.

Lippman'in "oydaşma oluşturma" terimi ile anlatmak istediği olgu politika kadar eskiyse de, basit deneylerin, sezginin ve sinama yanılmaya dayanan buluşların yerine bilimsel analiz yöntemlerinin konulması ve geliştirilmesi modern propagandanın ortaya çıkışıyla olmuştur. Psikolojik araştırmalardan elde edilen bulgular ve büyük haberleşme yenilikleri bu bilimsel yöntemlere eklendiğinde demokrasi uygulaması temelinde değişmiş; "ekonomik iktidarın değişmesine oranla bile, bu alanda, çok daha önemli bir devrimle" karşılaşılmıştır. Bu olgunun tamamlandığı yillarda siyasal hayatın kontrolünü ellerinde bulunduranlar "ikna sanatının kendine özgũ bir iş" ve "halka dayanan yönetimin en gerekli organ" olduğunu görmüşlerdir. Toplumda oydaşmanın nasıl yaratılabileceğini gösteren bllgiler bütün politik hesap ve düşünceleri değiştirmiş; çoklarının fark edemediği ölçüde, "bütün siyasal varsayımlarda değişikliklere yolaçmıştır." Bu koşullar altında, insan davranışlarının bilginin denetimi altında olduğu yolundaki demokrasinin kökenindeki dogma'nın kabulü; bu denetimin de "doğrudan doğruya insan doğasının sonucu olduğu" görüşünün anlamlı bulunması güçleşmeye başla- 
mıştır. Yeni koşullar altunda bu tür bir teoriyi temel olmak aldanmak ve gerçeklere uygunluğu gösterilemeyen "ikna biçimlerinin" etkisine açlmak tehlikesini görmezlikten gelmek olacaktır. Propaganda olgusu karşısında eğer dış dünya ile ilişki kurmak istiyorsa insanın eskisi gibi" vicdanın sesini dinlemesinin, sezgilerine güvenmesinin ya da etrafında rastlayabileceği samimi kanaatlan kendisine destek almasının olanaksızlaştığı açıkca ortaya çıkmış bulunuyordu. ${ }^{21}$

Kamu oyunun karakterini saptamak için giriştiği incelemeler sirasinda Lippmann "stereotype" terimini de ilk olarak kullanan yazar olmuştur. Bu terimle Lippmann, insanın şey'ler hakkında sahip olduğunu sandiğı bilgileri ifade etmiştir. Ancak, boş inanlara [myth] dayanan, asılsız "hayallere", vb. dayanan bu tür bilgilerin uyank insan aklının ürünü olan gerçek bilgilerden tamamen farklı şeyler olduğu belirtilmiştir. ${ }^{22}$ Belki de etkisinde kaldığ Sorel $^{23}$ gibi, Lippmann da, boş inançların, 'efsanelerin veya streooteype'lerin halk kitlelerinde heyecan ve çeşitli duygular yaratmakta kullanılabileceği görüşündeydi. Lippmann soyut inanışlarn, bir ulusun veya rrkın üyesi ya da bir yörenin yerlisi olmaktan duyulan gururun, eski geleneklerden şan ve öğüņ aramanın, bireysel arzularin ve halk kitlelerindeki "avamca" tutkuların basit halk kitleleri için gerçeklerin kendi varlığından çok daha büyük "gerçekler" yerine geçtiğini anlamıs bulunuyordu. Boş inanışlar ve "efsaneden" başka birşey sayılmaması gereken hikâyeler üzerinde demokratik teori fazla durmamış; bunlar derinlemesine incelememişti:. Propagandaclar ise, bunlara çok büyük bir önem veriyorlardı. Boş inanışlar ve "efsaneler" kavramları, yakalanmaları güç şeyler olduğu için bunları yoğurmak, istendiği şekilde biçimlendirmek gerçeklerle oynamaktan çok daha kolaydı. Diğer yandan, bunlar, inananlar için hayatın kendisi kadar gerçeklik kazanmış şeylerdi. Bu dönemde birkaç yil sonra Faşistler bir siyasal kontrol aracı olarak boş inanışların ve "efsanelerin" anlamı üzerinde durmaya başlamışlardır.

Fakat hemen belirtilmelidir ki, bos inanışar ve "efsaneler" sadece Faşistlere özgü bir olgu saylamaz. Mụssolini'nin sözlerini aktarırsak: "Bos inanıslar ve efsaneler bir iman, bir tutkudur. Bunla-

$21 \mathrm{Bu}$ paragraftaki alıntılar Public Opinion'dan, ss. 248-249.

22 "Gerçek bilgi" sözünün kullanılmasını doğru bulmayan bilgibilimciler lepistemologists] hakkındaki bilgiler Walter Lippmann'dandır. Konu üzerinde bizim durmamiz gereksiz.

23 G. Sorel, Reflection on Violence (London: Allen and Urwin, 1815), s6. 135 ve sonrasi. 
rın gerçekliğinin olması gerekmez. Myth'lerin gerçekliği bunların bir inanıs, bir umut, bir iman, bir cesaret kaynağı olmalarındandur."24 Propagandacllar için myth'ler en önemli stereotype örnekleridir. Insanlamn bilgi saydığı şeylerin pek çoğunun aslında sadece bir stereotype'ler kümesinden ibaret olduğunu bilmedikçe, bunun nedenini anlamadikça, propaganda olgusunun niçin bu denli etkin ve başarılı olduğu da anlaşılamaz.

Gerek siyasal hayatta bir etmen olarak ve gerekse akademik inceleme konusu olarak "propaganda" konusu, göreceli olarak, asıl bu yüzyılla birlikte gelişmeye başlamıştır. Bununla beraber, kamu oyunun kitlesel çapta denetim altına alınabilmesinin artık imkânsız bir şey olmadığını göremeyenler; bu olgunun önemini ve anlamını kavramayanlar yüzyılın başlarnnda da çoğunluk denecek saylarda olmaya devam etmişlerdir. Toplumun propaganda sorunu ile ilgilenmesi ve propaganda olgusunun farkına varması 1914-1918 savaşınin. etkisiyle olmuştur. Birinci Dünya Savaşının çağdaş propaganda anlayışı üzerindeki etkileri bundan sonraki bölümde ele alınacaktır.

24 B. Mussolini'nin 1822'de Napoli'de verdiği bir söylevden alan: H. Finer, Mussollni's Italy (New York: Henry Holt, 1935), s. 218. 